\title{
Camelina, an ancient oilseed crop actively contributing to the rural renaissance in Europe. A review
}

\author{
Federica Zanetti ${ }^{1}$ (D) Barbara Alberghini ${ }^{1}$ - Ana Marjanović Jeromela ${ }^{2}$. Nada Grahovac ${ }^{2} \cdot$ Dragana Rajković $^{2}$. \\ Biljana Kiprovski ${ }^{2} \cdot$ Andrea Monti $^{1}$
}

Accepted: 2 December 2020 / Published online: 6 January 2021

(C) The Author(s) 2021

\begin{abstract}
Promoting crop diversification in European agriculture is a key pillar of the agroecological transition. Diversifying crops generally enhances crop productivity, quality, soil health and fertility, and resilience to pests and diseases and reduces environmental stresses. Moreover, crop diversification provides an alternative means of enhancing farmers' income. Camelina (Camelina sativa (L.) Crantz) reemerged in the background of European agriculture approximately three decades ago, when the first studies on this ancient native oilseed species were published. Since then, a considerable number of studies on this species has been carried out in Europe. The main interest in camelina is related to its (1) broad environmental adaptability, (2) low-input requirements, (3) resistance to multiple pests and diseases, and (4) multiple uses in food, feed, and biobased applications. The present article is a comprehensive and critical review of research carried out in Europe (compared with the rest of the world) on camelina in the last three decades, including genetics and breeding, agronomy and cropping systems, and end-uses, with the aim of making camelina an attractive new candidate crop for European farming systems. Furthermore, a critical evaluation of what is still missing to scale camelina up from a promising oilseed to a commonly cultivated crop in Europe is also provided (1) to motivate scientists to promote their studies and (2) to show farmers and end-users the real potential of this interesting species.
\end{abstract}

Keywords Multipurpose $\cdot$ Oil $\cdot$ Protein $\cdot$ Bioeconomy $\cdot$ Double cropping $\cdot$ Mixed cropping

\section{Contents}

1. Introduction

2. Morphological description and main agronomic traits

3. Sustainable cultivation strategies for Europe

3.1 Camelina as the main crop in marginal soils

3.2 Camelina as a cover crop in a double-cropping system

3.3 Camelina as a mixed or relay crop with legumes or grasses

4. Seed qualitative traits and food uses

5. Non-food uses and innovative applications

5.1 Biofuels

5.2 Hydraulic fluids and biopolymers

5.3 Feed

Federica Zanetti

federica.zanetti5@unibo.it

1 Department of Agricultural and Food Sciences (DISTAL), Università di Bologna - Alma Mater Studiorum, Viale G. Fanin 44,

Bologna 40127, Italy

2 Institute of Field and Vegetable Crops, Maksima Gorkog 30, Novi Sad 21000, Serbia

\subsection{Cosmetics}

6. Genetic diversity and breeding strategies

7. Strengths, weaknesses, opportunities and threats (SWOT) of camelina in Europe

8. Conclusions

References

\section{Introduction}

European agriculture relies mostly on a few staple crops widely grown in different regions, and only two species account for approximately $90 \%$ of the total arable area of oilseed crops (source: Eurostat): sunflower (Helianthus annuus L.), mainly grown in southern and eastern Europe with a spring cycle, and oilseed rape (Brassica napus var. oleifera L.), cultivated mainly in central Europe with an autumn cycle or in northern Europe with a spring cycle. These oilseed species are often included in rotations with winter cereals, root crops, and pulses, but crop diversification of agricultural systems in Europe is generally limited to a few crops despite indisputable 
benefits to the environment and the rural economy (Adeux et al. 2019; Li et al. 2019; Lin 2011). In this scenario, camelina (Camelina sativa (L.) Crantz) is receiving increasing attention worldwide by either the scientific community, farmers, or end-users. Camelina is a native European species, where it has been widely cultivated until the beginning of the twentieth century, when it was replaced by the more productive oilseed rape (Berti et al. 2016). Most recently, in the framework of different EU projects (e.g., ITAKA, ICON, COSMOS), camelina has been rediscovered as a multipurpose crop as a source of both oil and protein (Righini et al. 2016), adopting low-input and cost-competitive agronomic management (Tonin et al. 2018). Due to the large interest in this species in Europe and being the driving forces for this interest, the authors consider it imperative to collect all European knowledge on camelina to provide guidelines for the future sustainable development of this species.

Interest in camelina is witnessed by numerous scientific publications concerning this species (i.e., camelina) and 1156 references in SCOPUS in the period 1923March 2020. Since 1997, at least five articles per year have been published containing the word camelina, which has increased to at least 100 articles per year since 2015. The maximum value was reached in 2019, with 131 publications on this crop. Approximately one-third of the publications on camelina include European authors (390 vs. 1156, European vs. total publications), and the countries most focused on this oilseed crop are Poland (68), Germany (45), Spain (42), the UK (41), Romania (38), France (33), and Italy (29).

Camelina has attracted the attention of European scientists as a source of healthy oil to be used in food and feed applications (Zubr 1997, 2009) in relation to its peculiar fatty acid composition, particularly high in longchain polyunsaturated fatty acids (PUFAs) and tocopherols (Berti et al. 2016). In the framework of the ITAKA project, camelina was identified as an optimal source of oil to be converted into jet fuel (Lobo et al. 2015). Camelina has been thoroughly studied as a source of fat and protein for animal feed, with the oil being particularly suitable for aquaculture applications (Hixson et al. 2014a,b) and the cake being highly valued as a protein source for poultry, both broiler and laying hens (Aziza et al. 2010; Cherian et al. 2009). Currently, in Europe, the main camelina applications on the commercial scale are the use of oil as food dressings and the inclusion of the cake in animal feed. To date, camelina is cultivated in Europe in an area probably exceeding 10,000 ha per year, with a relevant share under organic farming. Nevertheless, official data regarding the cultivation area are not publicly available. Further upscaling of this crop is expected soon in relation to its unique agronomic characteristics and multiple end-uses.

\section{Morphological description and main agronomic traits}

Camelina is an annual dicot species belonging to the Brassicaceae family. Both winter and spring biotypes are available, and within each biotype, different cultivars, genotypes, and GenBank accessions are present. Camelina growth cycle ranges between 90 and 250 days (Czarnik et al. 2018; Hrastar et al. 2012; Krzyżaniak et al. 2019; Martinelli and Galasso 2011; Masella et al. 2014; Royo-Esnal and Valencia-Gredilla 2018; Zanetti et al. 2017; Zubr 1997). Regarding the camelina cycle length, expressed as growing degree day (GDD), differences in terms of duration were even more restrained, as evidenced in Table 1, where an average of 1200 GDD results as the mean value accumulated from sowing to harvest, depending on the sowing season and date.

Camelina shows remarkable morphological plasticity, as sowing rate and growing conditions affect plant size and the number of lateral shoots (Martinelli and Galasso 2011). After the development of a pair of true leaves (Fig. 1a) on the first node, the following leaves grow alternatively on consecutive nodes (Fig. 1b) until the formation of a rosette (Martinelli and Galasso 2011). Camelina can reach a final height ranging from 0.65 to $1.05 \mathrm{~m}$ (Czarnik et al. 2018; Jankowski et al. 2019; Masella et al. 2014; Vollmann et al. 2007; Załuski et al. 2020) and form up to 30 lateral branches (Fig. 1c) (Martinelli and Galasso 2011). The inflorescence is composed of small pale-yellow flowers (Fig. 1d), which are made up of four petals that further develop pear-shaped silicles (Fig. 1e). The final number of silicles per plant can range from approximately 60 to 115 , and it is positively and negatively correlated with increased $\mathrm{N}$ fertilization and increased sowing density, respectively (Czarnik et al. 2017, 2018). At the end of their expansion, silicles are 4-5 mm wide and 6-8 $\mathrm{mm}$ long (Martinelli and Galasso 2011). During ripening, silicles change their color from green to yellow-reddish and then completely dry at full maturity (Fig. 1f). Each silique can contain 10-20 small seeds (Czarnik et al. 2017; Jankowski et al. 2019; Martinelli and Galasso 2011). In fact, 1000-seed weight varies from 0.7 to $1.8 \mathrm{~g}$ (Angelini et al. 1997; Czarnik et al. 2017, 2018; Jankowski et al. 2019; Righini et al. 2019; Vollmann et al. 2007; Załuski et al. 2020; Zanetti et al. 2017; Zubr 1997). Older studies report a negative correlation between seed weight and both seed and oil yield. Contrary to these findings, Zanetti et al. (2017) reported more recently that in new improved camelina lines, characterized by increased seed weight, seed yield was higher in comparison to lines with average seed weight, and seed oil content was comparable.

Research carried out across Europe demonstrates that camelina seed yield is influenced by both climate and cultivar (Table 2). Camelina seed production in European environments ranges between 1.3 and $3.3 \mathrm{Mg} \mathrm{DM} \mathrm{ha}{ }^{-1}$ (Angelini et al. 1997; Czarnik et al. 2017, 2018; Jankowski et al. 
Table 1 Camelina cycle length expressed as duration in days and in growing degree days in different European locations
Fig. 1 Details of the camelina plant. a First pair of true leaves in emerged camelina plants. b Camelina plants at the rosette stage. c Camelina branches. d Camelina inflorescences. e Pearshaped camelina silicles. f Camelina silicles near maturity

\begin{tabular}{lllll}
\hline Country & $\begin{array}{l}\text { Sowing } \\
\text { season }\end{array}$ & Cycle length (days) & GDD & References \\
\hline
\end{tabular}

\begin{tabular}{|c|c|c|c|c|}
\hline Denmark & Spring & 120 & & Zubr (1997) \\
\hline Italy & Spring & 110 & & Martinelli and Galasso (2011) \\
\hline Slovenia & Spring & 110 & & Hrastar et al. (2012) \\
\hline Italy & $\begin{array}{l}\text { Spring } \\
\text { Autumn }\end{array}$ & $\begin{array}{l}115 \\
220\end{array}$ & & Masella et al. (2014) \\
\hline $\begin{array}{l}\text { Greece } \\
\text { Italy }\end{array}$ & Spring & & $\begin{array}{l}1266-1300^{1} \\
1117-1226^{1}\end{array}$ & Zanetti et al. (2017) \\
\hline Poland & & & $933-1411^{1}$ & \\
\hline Poland & Autumn & 291 & & Czarnik et al. (2017) \\
\hline Spain & $\begin{array}{l}\text { Autumn } \\
\text { Winter }\end{array}$ & $\begin{array}{l}163-221 \\
123-150\end{array}$ & $\begin{array}{l}1897-2575^{2} \\
1720-2174^{2}\end{array}$ & $\begin{array}{l}\text { Royo-Esnal and Valencia-Gredilla } \\
\text { (2018) }\end{array}$ \\
\hline Poland & Spring & $97-135$ & $1019-1389^{1}$ & Krzyżaniak et al. (2019) \\
\hline Italy & $\begin{array}{l}\text { Autumn } \\
\text { Spring }\end{array}$ & & $\begin{array}{l}982-1123^{1} \\
1000-1345\end{array}$ & Righini et al. (2019) \\
\hline
\end{tabular}

${ }^{1} T_{\text {base }}=5^{\circ} \mathrm{C}$

${ }^{2} T_{\text {base }}=-0.7^{\circ} \mathrm{C}$
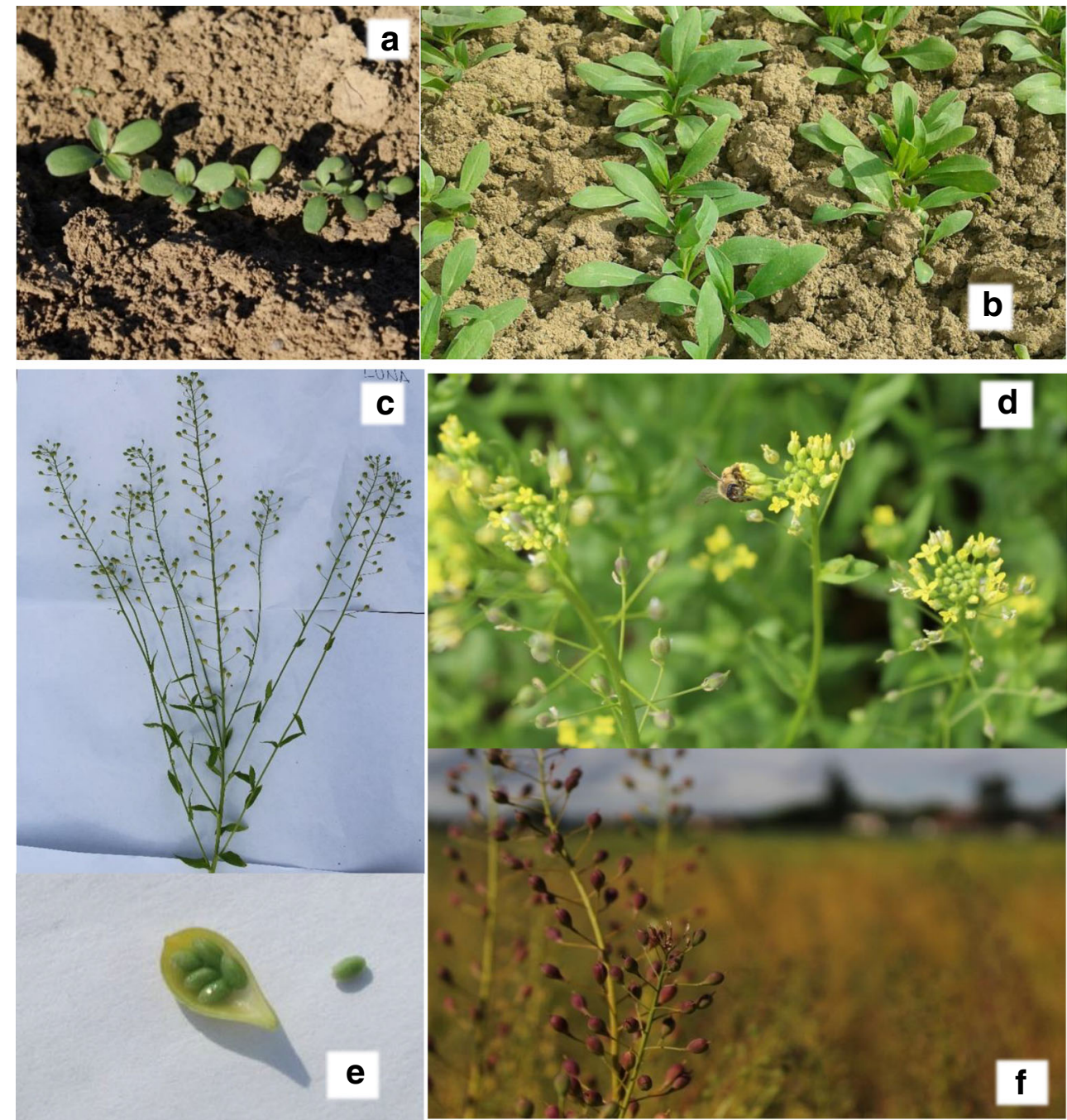
Table 2 Camelina seed yield ( $\mathrm{Mg}$ $\mathrm{DM} \mathrm{ha}^{-1}$ ) and seed oil content (\% $\mathrm{DM})$ as reported in studies carried out across different European locations. Sowing season: $S$ spring, $A$ autumn, $W$ winter

\begin{tabular}{|c|c|c|c|c|c|}
\hline Country & Location & $\begin{array}{l}\text { Sowing } \\
\text { season }\end{array}$ & $\begin{array}{l}\text { Seed yield range } \\
\left(\mathrm{Mg} \mathrm{DM} \mathrm{ha}^{-1}\right)\end{array}$ & $\begin{array}{l}\text { Seed oil } \\
\text { content }(\%)\end{array}$ & References \\
\hline Austria & Groß-Enzersdorf & $\mathrm{S}$ & $1.6-2.2$ & & Vollmann et al. (2007) \\
\hline \multirow[t]{3}{*}{ Denmark } & Taastrup & A & 3.3 & $44.8-46.7$ & Zubr (1997) \\
\hline & & $\mathrm{S}$ & 2.6 & $40.4-43.4$ & \\
\hline & Taastrup, Borris & $\mathrm{S}$ & & $41.3-44.6$ & Zubr (2003) \\
\hline Germany & $\begin{array}{l}\text { Müllheim, } \\
\text { Paderborn }\end{array}$ & $\mathrm{S}$ & & $41.3-44.6$ & Zubr (2003) \\
\hline Greece & Aliartos & $\mathrm{S}$ & 1.2 & & Zanetti et al. (2017) \\
\hline Finland & Helsinki & & & $41.3-44.6$ & Zubr (2003) \\
\hline Ireland & Carlow & $\mathrm{S}$ & & $41.3-44.6$ & Zubr (2003) \\
\hline \multirow[t]{6}{*}{ Italy } & Pisa & $\mathrm{S}$ & & $24-33$ & Angelini et al. (1997) \\
\hline & Bergamo & $\mathrm{S}$ & $1.5-2.1$ & & Masella et al. (2014) \\
\hline & & A & $1.2-3.4$ & & \\
\hline & Bergamo & $\mathrm{S}$ & & $29-37$ & Pecchia et al. (2014) \\
\hline & & $\mathrm{A}$ & & $28-33$ & \\
\hline & Bologna & $\mathrm{S}$ & 1.9 & & Zanetti et al. (2017) \\
\hline Norway & Apelsvoll & $\mathrm{S}$ & & $40.4-41.8$ & Kirkhus et al. (2013) \\
\hline \multirow[t]{8}{*}{ Poland } & Kętrzyn & $\mathrm{S}$ & 1.7 & & Zanetti et al. (2017) \\
\hline & Przecław & $\mathrm{S}$ & $1.7-1.9$ & & Czarnik et al (2017) \\
\hline & Przecław & A & $1.6-3.1$ & & Czarnik et al. (2018) \\
\hline & Dłoń & $\mathrm{S}$ & $0.7-2.2$ & & $\begin{array}{l}\text { Kurasiak-Popowska et al. } \\
\quad(2018)\end{array}$ \\
\hline & & $\mathrm{A}$ & $1.1-2.2$ & & \\
\hline & $\begin{array}{l}\text { Samławki, } \\
\text { Kocibórz }\end{array}$ & $\mathrm{S}$ & $1.2-1.4$ & $35.2-38.2$ & Stolarski et al. (2018) \\
\hline & Bałcyny & $\mathrm{S}$ & $1.5-2.5$ & $36.6-42.2$ & Jankowski et al. (2019) \\
\hline & Łężany & $\mathrm{S}$ & $2.0-2.2$ & $39.3-42.2$ & Krzyżaniak et al. (2019) \\
\hline Slovenia & Koroška region & $\mathrm{S}$ & & $28.8-40.2$ & Hrastar et al. (2012) \\
\hline \multirow[t]{2}{*}{ Spain } & Lleida & A & $0.6-2.4$ & & $\begin{array}{l}\text { Royo-Esnal and } \\
\text { Valencia-Gredilla } \\
\text { (2018) }\end{array}$ \\
\hline & & W & $1.0-2.1$ & & \\
\hline Sweden & Uppsala & $\mathrm{S}$ & & $41.3-44.6$ & Zubr (2003) \\
\hline UK & $\begin{array}{c}\text { Headley Hall, } \\
\text { Tadcaster }\end{array}$ & $\mathrm{S}$ & & $41.3-44.6$ & Zubr (2003) \\
\hline
\end{tabular}

2019; Krzyżaniak et al. 2019; Kurasiak-Popowska et al. 2018; Masella et al. 2014; Royo-Esnal and Valencia-Gredilla 2018; Stolarski et al. 2018; Vollmann et al. 2007; Załuski et al. 2020; Zanetti et al. 2017; Zubr 1997). Seed yield is strongly affected by weather conditions and is higher with milder temperatures during the growing season (Jankowski et al. 2019; Krzyżaniak et al. 2019; Załuski et al. 2020; Zanetti et al. 2017; Zubr 1997). Moreover, increasing sowing density and $\mathrm{N}$ fertilization results in greater production (Czarnik et al. 2018; Zubr 1997). Early research by Zubr (1997) reported winter camelina cultivars as more productive than spring cultivars; however, more recent publications (Zanetti et al. 2017, Righini et al. 2019, Zanetti et al. 2020) showed an opposite trend, with spring cultivars being able to outclass winter cultivars. Obviously, the possibility of sowing spring camelina in autumn is confined to regions where the winter air temperature never exceeds -10 to $-14{ }^{\circ} \mathrm{C}$ (Soorni et al. 2017); thus, the direct comparison between spring and winter types is geographically very limited (Christou et al. 2018). We could speculate that with the major part of camelina breeding carried out in spring types to date, the reason for the higher productivity of spring cultivars compared with winter cultivars reported in the most recent literature is linked to their improved genetic pedigree. In general, early sowing both in autumn and in spring significantly increases camelina productivity (Czarnik et al. 2018; Righini et al. 2019). Seed yield and oil yield are positively 
correlated (Vollmann et al. 2007; Zanetti et al. 2017). Oil yield is usually in the range of $0.6-1.0 \mathrm{Mg} \mathrm{DM} \mathrm{ha}^{-1}$ (Krzyżaniak et al. 2019; Vollmann et al. 2007; Zanetti et al. 2017), and seed oil content ranges from 36 to $43 \%$, being higher in winter cultivars than in spring cultivars (Jankowski et al. 2019; Kirkhus et al. 2013; Krzyżaniak et al. 2019; Stolarski et al. 2018; Załuski et al. 2020; Zanetti et al. 2017; Zubr 1997). In a study carried out in Poland by Krzyżaniak et al. in 2019, camelina oil content was influenced mainly by temperature and precipitation during the growing season, with the highest oil content observed in years with high temperatures and low precipitation. Righini et al. (2019), when comparing autumn and spring sowing dates in Italy, found an increased seed oil content when the flowering and seed-filling phases occurred at lower temperatures (i.e., autumn sowing). Jankowski et al. (2019) reported that increased $\mathrm{N}$ fertilization reduces seed oil content.

\section{Sustainable cultivation strategies for Europe}

The introduction, or in this case, the reintroduction, of a new species in a new environment encompasses meeting the needs of the different actors along the value chain (farmers, endusers of oil and cake, policymakers). Camelina was first identified as a suitable replacement for oilseed rape in areas characterized by lower fertility or even marginal soils (Von Cossel et al. 2019). This aspect has been broadly investigated in Canada (Blackshaw et al. 2011), where canola and camelina both have spring cycles. In Europe, this type of study has not yet been carried out, mainly because camelina is still a niche crop, with a spring cycle, and generally oilseed rape, in autumn, is grown in deep and fertile soils in continental areas of France, Germany, and Poland. Thus, the direct comparison between the two species, as well as the possible replacement of one crop with the other, in terms of not only productivity but also possible effects in the rotation schemes, is lacking in the available literature. Otherwise, in continental areas of Poland, where camelina was widely cultivated until 1955 (Muśnicki et al. 1967), this crop can represent a valuable option for replacing oilseed rape failing to establish in autumn. Due to uneven precipitation patterns and the increase in the occurrence of extreme weather events, this scenario has become increasingly frequent in recent years. In Poland and Ukraine, winter camelina cultivars were traditionally cultivated (Kurasiak-Popowska et al. 2018) since that area was identified as one of the camelina centers of origin.

The undisputable agronomic plasticity of camelina has more recently attracted the attention of scientists and growers since it is one of the unique European crops able to fit easily into diverse cropping systems, both under conventional and organic farming (Bilalis et al. 2017; Royo-Esnal and
Valencia-Gredilla 2018). One of the winning features of camelina remains its full adaptability to available agricultural equipment on farms (Sindelar et al. 2017), which is often identified as a major barrier for the feasible development of a new crop.

Apart from the direct replacement of oilseed rape, three cropping strategies have been identified as the most suitable for growing camelina in Europe:

1. A) as the main crop in marginal soils where there is no possibility to grow alternative staple species, apart from winter cereals, as the sole crop;

2. B) as a cover crop, with both winter and summer cycles, between two main crops in double cropping systems (= form of sequential cropping in which two crops are grown in sequence within a year on a piece of land, one after the harvest of the other, FAO definition);

3. C) as mixed cropping systems (= growing two or more crops simultaneously in the same field, FAO definition) or relay cropping (= form of intercropping growing two or more crops in a sequence usually planting the succeeding crop after the flowering, but before the harvesting of the preceding crop, FAO definition) in combination with legumes or grasses.

Included in any of the three abovementioned systems, camelina will promote biodiversity, decrease soil erosion, improve water infiltration (Gaba et al. 2015; Meyer et al. 2019), and foster the sustainable intensification of cropping systems (Sindelar et al. 2017; Struik and Kuyper 2017). Furthermore, option $C$ ) is particularly valuable and widespread, especially in organic farming, where the combination of more than one species to overcome weed pressure is often adopted (Leclère et al. 2019; Gollner et al. 2010; Saucke and Ackermann 2006).

\subsection{Camelina as the main crop in marginal soils}

This type of cultivation strategy can be adopted with both spring and winter camelina cultivars (Stolarski et al. 2018, 2019). Furthermore, in milder environments of the Mediterranean basin such as Spain (Martinez et al. 2020) and Italy (Bacenetti et al. 2017), spring camelina adapts well to be grown with an autumn cycle in marginal soils. Mauri et al. (2019) reported that spring camelina sown in autumn under semi-arid conditions in central Spain achieved an average seed yield of $1 \mathrm{Mg} \mathrm{DM} \mathrm{ha}^{-1}$ in a 2-year study. This value might be considered a reliable yield threshold for the profitable cultivation of camelina in marginal or semi-marginal soils, as also reported by Stolarski et al. (2018). Otherwise, in the northern semi-arid land of Spain, spring camelina, grown with an autumn cycle, was able to reach seed yields often above $2 \mathrm{Mg} \mathrm{DM} \mathrm{ha}{ }^{-1}$, as reported by Royo-Esnal and Valencia-Gredilla (2018). 


\subsection{Camelina as a cover crop in a double-cropping system}

Attention toward the use of cover crops is rapidly increasing in Europe, mainly in relation to their undeniable environmental benefits (Constantin et al. 2015; Petit et al. 2018), but more recently, in studies conducted together with farmers, adopting a participatory approach, camelina was identified as a possible summer cover crop in double cropping systems in northern France (Leclère et al. 2018). This type of approach tremendously widens the opportunities of camelina to pass from the status of niche crop to cash cover crop in Europe. Cash cover crops have been defined by Gesch et al. (2014) as cover crops able to reach seed maturity before the establishment of the main crop, thus providing an additional income to farmers. Groeneveld and Klein (2013) demonstrated that growing camelina as a summer cover, after strawberry (Fragaria $\times$ ananassa), enhanced insect biodiversity, providing foraging resources at time when very few other plants are usually flowering. In the milder environments of northern Italy and central Greece, Zanetti et al. (2019) demonstrated the feasibility of growing camelina as a winter cover crop before maize (Zea mays L.). Reported results confirmed the suitability of camelina to fit as a preceding crop before typical summer cereals, but other alternative succeeding crops such as sunflower or soybean (Glycine $\max$ L. Merr) can also be sown after camelina. The choice of the crop to match camelina should be carried out locally to fulfill farmers' expectations and needs. One of the main advantages of camelina toward other competing crops, also belonging to the Brassicaceae family (i.e., Crambe abyssinica, B. napus), is the shorter cycle, allowing the sowing of a second crop and likely aiding in reducing nematodes. Camelina has been reported to reduce soybean cyst nematodes (Heterodera glycines Ichinohe) (Acharya et al. 2019).

\subsection{Camelina as a mixed or relay crop with legumes or grasses}

Mixed cropping systems, either as full-mix or relay crops, are often widespread in areas with environmental limitations, i.e., northern latitudes, where the growing season is too short to allow growing two crops in one season (Berti et al. 2015). However, more recently, this type of system has also become popular in other areas in relation to constraints linked to water scarcity, weed and disease pressure, and soil limitations (Gaba et al. 2015); thus, growing two crops at the same time has become of interest among growers. Several authors (Carton et al. 2020; Gollner et al. 2010; Leclère et al. 2019; Paulsen 2007, 2011; Saucke and Ackermann 2006) demonstrated that camelina can be successfully grown when mixed with peas (Pisum sativum L.), lentils (Lens culinaris L.), and lupins (Lupinus angustifolius L. or Lupinus album L.) without consistent seed yield losses in both species and without the need for any chemical weed control. Unfortunately, the majority of the abovementioned studies, apart from Carton et al. (2020), report mixed cropping sown in spring, thus confirming the lack of research on European studies considering camelina as a winter crop. Mixed cropping is highly valuable for organic farming systems where experiences with camelina grown together with soybean and lentil are reported in France (Source: ITAB, France) and Austria (Gollner et al. 2010). Otherwise, experiences on camelina mixed cropping with cereals (i.e., barley (Hordeum vulgare) and wheat (Triticum sp.)) often result in a high reduction in camelina yield (Leclère et al. 2019; Paulsen 2011), mainly in relation to strong competition with grasses at early stages. In systems including camelina and legume crops, the low vegetative growth at the early stage of the latter is compensated by early vigor of the camelina, thus preventing any weed emergence.

European experiences in relay cropping systems, including camelina and other species, are completely lacking in the reviewed literature, but there are experiences in Canada reporting the feasibility of relaying crop camelina and chickpea (Cicer arietinum), for example (personal communication C. Eynck). More research in this field is surely needed to fully exploit the potential of this new oilseed crop.

\section{Seed qualitative traits and food uses}

The high amounts of essential fatty acids (FAs) and natural anti-oxidants add nutritive value to camelina seeds. These compounds of interest are PUFAs, phenolic compounds, tocopherols, carotenoid pigments, vitamins, phospholipids, and phytosterols. The oil content in the seed (Table 3) ranges from 28 to $49 \%$ DM (dry matter) (Krzyżaniak et al. 2019). The oil consists of approximately $50 \%$ PUFAs, of which $\alpha$-linolenic acid (C18:3, ALA) accounts for almost 28-50\%, while linoleic acid (C18:2, LA) accounts for approximately 15$23 \%$ of all FAs (Krzyżaniak et al. 2019; Kurasiak-Popowska et al. 2019). Camelina seeds have a favorable ratio of omega-3 ( $\omega-3)$ to omega-6 ( $\omega-6)$ acids, which varies from 1.3 to 2.6 (Kurasiak-Popowska et al. 2019; Rodríguez-Rodríguez et al. 2013). Oleic, eicosenoic (C20:1) and palmitic acids (C16:0) were found in lower concentrations (Table 3). The amount of erucic acid (C22:1) in camelina oil is naturally quite low and always below $4 \%$. This value is significantly lower than in other members of the Brassicaceae family (Budin et al. 1995). Like oilseed rape, camelina cultivars (KurasiakPopowska et al. 2019, 2020) and genetically edited lines (Jiang et al. 2017) have extremely low levels of erucic acid $(\sim 0 \%)$. Furthermore, camelina seeds are characterized by a relatively high protein content ranging from 24.5 to $31.7 \%$ of their mass. The proteins in camelina seeds are rich in essential amino acids, with leucine, valine, lysine, 

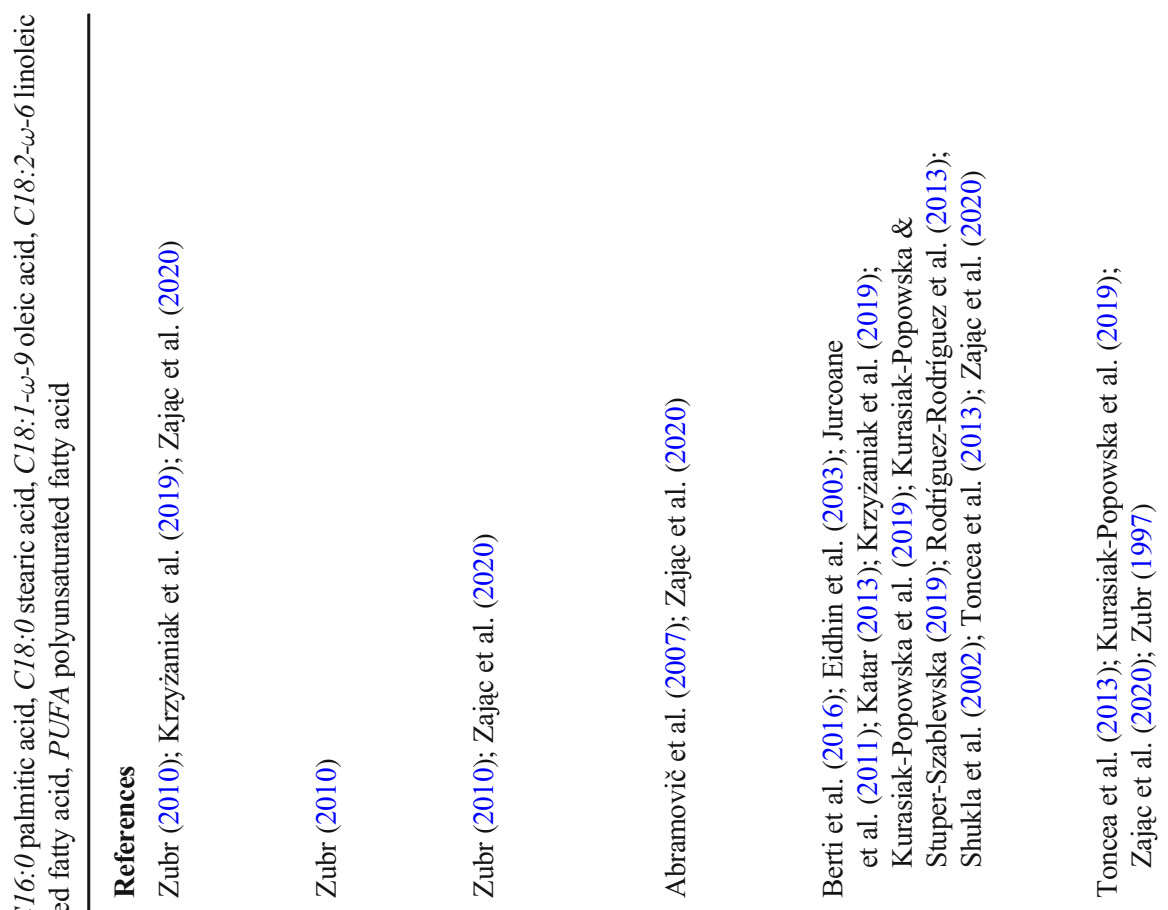

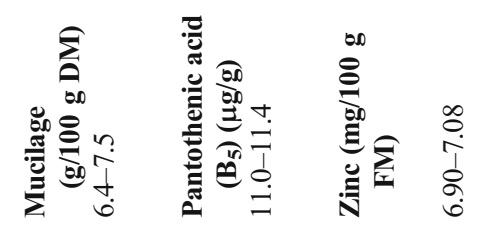

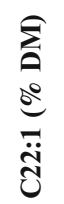

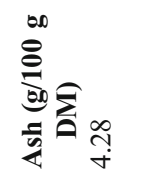

$\stackrel{\frac{\partial 0}{60}}{\frac{50}{20}}$

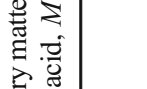

농

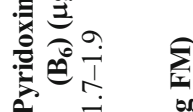

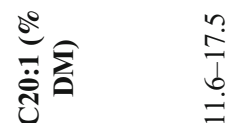

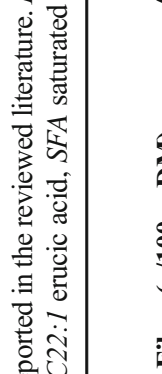

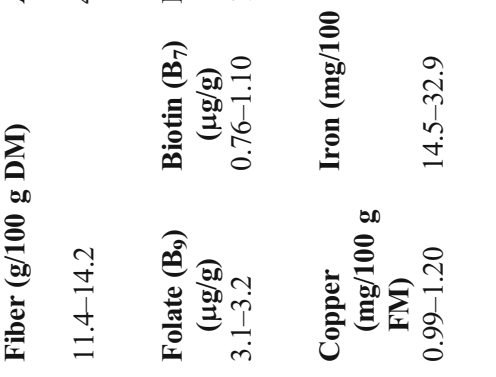

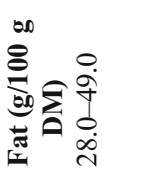

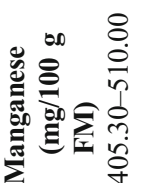

产

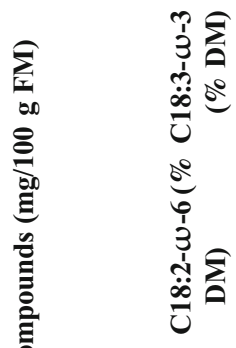

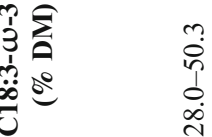

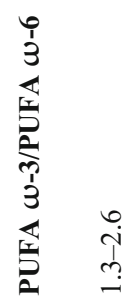

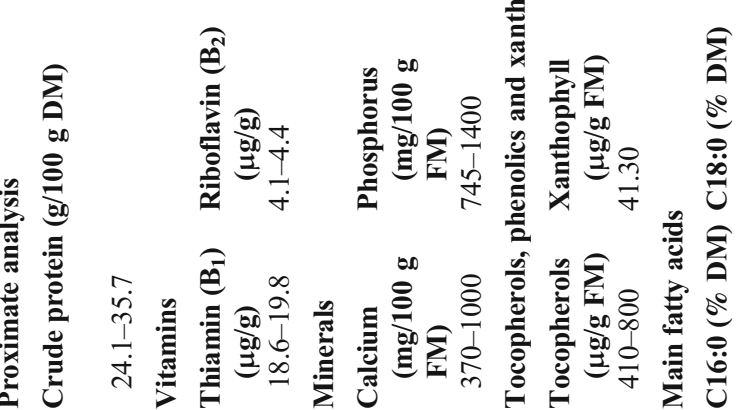

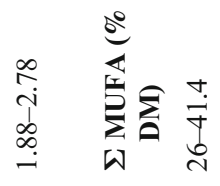

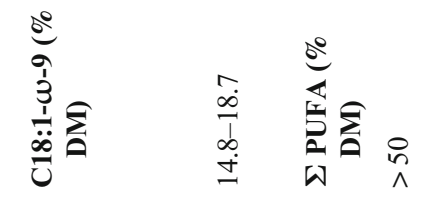

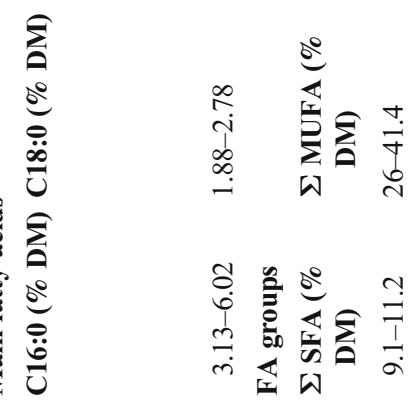


phenylalanine, and isoleucine as the major constituents (Table 4). In addition to essential amino acids, proteins in camelina seeds are rich in non-essential amino acids as well, mostly glutamic and aspartic acids, arginine, proline, and serine (Bătrîna et al. 2020; Zubr 2003). Apart from PUFAs and proteins, camelina seed is rich in anti-oxidants, such as phenolic acids and flavonoids, tocopherols, and xanthophyll (Table 3) (Kurasiak-Popowska et al. 2019; Taranu et al. 2014; Zubr and Matthäus 2002; Terpinc et al. 2012; Zając et al. 2020). Among tocopherols, gamma tocopherol accounts for approximately $90 \%$ of the total (Abramovič et al. 2007). In addition to anti-oxidant activity, these compounds affect oil taste and color (Kurasiak-Popowska et al. 2019). Many of these anti-oxidants stabilize oils and protect unsaturated fatty acids from oxidation, thus significantly extending the shelf life of camelina oil.

Furthermore, camelina seeds provide minerals, especially phosphorus, manganese, calcium, and iron (Table 3) (Zając et al. 2020), as well as several vitamins, mostly vitamins $B_{3}$ (190-212 $\left.\mu \mathrm{g} \mathrm{g}^{-1}\right), \mathrm{B}_{1}\left(18.6-19.8 \mu \mathrm{g} \mathrm{g}^{-1}\right)$, and $\mathrm{B}_{5}(11.0-$ $11.4{\mu \mathrm{g} \mathrm{g}^{-1}}$ ) (Table 3).

Camelina meal contains approximately $45 \%$ protein with a favorable composition of amino acids (threonine, methionine, glycine, lysine, and cysteine), like soy meal (Pekel et al. 2009, 2017; Zubr 1997). In addition, camelina meal is a high-quality feedstock with enhanced anti-oxidant capacity due to the high level of anti-oxidants in the seeds (Berti et al. 2016; Popa et al.

Table 4 Amino acid composition of proteins from camelina seed (Zubr 2003; Bătrîna et al. 2020)

\begin{tabular}{lc}
\hline Amino acid & Content $(\mathrm{g} / 100 \mathrm{~g})$ \\
\hline Essential amino acids & \\
Histidine & $2.60-4.06$ \\
Isoleucine & $3.96-4.62$ \\
Leucine & $6.63-7.12$ \\
Lysine & $4.46-4.52$ \\
Methionine & $1.72-2.85$ \\
Phenylalanine & $4.19-5.22$ \\
Threonine & $2.75-2.89$ \\
Tryptophan & $1.21-1.32$ \\
Valine & $5.42-6.34$ \\
Non-essential amino acids \\
Alanine & $4.61-6.14$ \\
Arginine & $8.15-8.57$ \\
Aspartic acid & $8.71-9.04$ \\
Glutamic acid & $14.98-16.12$ \\
Glycine & $5.25-6.06$ \\
Cystine & $1.94-2.12$ \\
Proline & $5.09-6.07$ \\
Serine & $5.04-5.96$ \\
Tyrosine & $3.04-3.64$ \\
\hline
\end{tabular}

2017; Woyengo et al. 2016). Nonetheless, in comparison to alternative sources such as soy meal, camelina meal contains different anti-nutritive compounds such as glucosinolates (14$\left.25 \mu \mathrm{mol} \mathrm{g}{ }^{-1}\right)$, phytate1 (20-22 $\left.\mathrm{mg} \mathrm{g}^{-1}\right)$, sinapine $\left(\sim 4 \mathrm{mg} \mathrm{g}^{-1}\right)$, and related phenolic acids (22-20 $\mathrm{mg} \mathrm{g}^{-1}$ ) (Schuster and Friedt 1998; Matthäus and Angelini 2005; Matthäus and Zubr 2000; Russo and Reggiani 2012; Russo et al. 2014; Zubr 1997). However, in camelina, the majority of these anti-nutritive compounds are contained in equal or slightly lower amounts when compared with canola quality oilseed rape.

The ingestion of camelina seeds shows positive effects on gastrointestinal processes in humans due to the high contents of mucilage, crude fiber, and lignin. The beneficial role of these ingredients in digestion is confirmed by long-term human consumption of bread enriched with camelina seeds available in the Danish supermarkets in various recipes (Zubr 2010). When extracted, fibers are valued as supplements in the human diet, while mucilage can easily find pharmaceutical and food applications (Fabre et al. 2020; Ubeyitogullari and Ciftci 2020). Due to the presence of bioactive compounds with beneficial effects on human health, oil produced from cold-pressed camelina seeds is extremely valuable (Ubeyitogullari and Ciftci 2020; Schmidt and; Pokorný 2005) since the majority, but not all, of them are soluble in oil. The high amount of ALA in camelina could be used as a dietary supplement for the human diet since it can repair the $\omega-3 / \omega-6$ balance in plasma. However, many studies have shown that ALA is converted to eicosapentaenoic (EPA; C20:5, $\omega-3$ ) and docosahexaenoic (DHA; C22:6, $\omega-3)$ acids via elongation and desaturation enzymes in the human body (De Lorgeril et al. 1994; Eidhin et al. 2003). The human diet is characterized by the inclusion of high levels of LA and low levels of ALA in contemporary diets, making the conversion of ALA to EPA and DHA very limited (Eidhin et al. 2003); thus, the inclusion of camelina oil could positively counterbalance this situation. The lack of $\omega-3$ FAs is even more serious in vegetarian and vegan diets where supplementation with those FAs is often compulsory. In relation to previous findings, there is an increasing occurrence of diet-dependent diseases such as cholesterolemia, hypertension, atherosclerosis, obesity, and some types of cancer (Arnold et al. 2010; Laviano et al. 2013; Kurasiak-Popowska et al. 2019; Simopoulos 1991 and 2016). The required level of at least $450 \mathrm{mg}$ per day of EPA + DHA fatty acids (WHO) cannot be met by the annual global supply of fish from the current marine fish stocks, which highlights the large gap between supply and demand (Cunnane 2004; Scientific Advisory Committee on Nutrition 2004; GOED 2014; Betancor et al. 2017; Tocher 2015; West et al. 2019). Accordingly, there is an enormous demand for alternative sustainable sources of EPA, DHA, and ALA to match global requirements (Baker et al. 2016). Camelina oil has great potential for use in the production of health-promoting foods due to its unique composition 
and beneficial health impact. Manninen et al. (2019) observed that human volunteers including camelina oil $\left(10 \mathrm{~g} \mathrm{day}^{-1}\right)$ in their diet had a significant increase in the proportion of ALA in erythrocyte membranes, cholesterol esters, triglycerides, and plasma phospholipids. Additionally, Faustino et al. (2016) investigated obtaining human milk fat from camelina oil as a potential substitute for infants. Several studies have confirmed that camelina $\omega-3$ fatty acids have antiinflammatory properties since they can be used as therapy for inflammatory diseases. In some European countries, camelina oil is used in traditional medicine as a cure for duodenal and stomach ulcers, as well as locally for eye inflammation as well as wound and burn healing (Ibrahim and El Habbasha 2015; Rode 2002; Terpinc et al. 2012). Due to its potential beneficial effects on human health, in Europe, camelina oil continues to be consumed in the diet, mostly as an ingredient of salad dressings (Lohaus 2019; Zubr 2003) but also as cooking oil, in spreads and margarines, as well as for the preparation of $\omega-3$ fatty acid-enriched products (Abramovic and Abram 2005; Zubr 1997).

\section{Non-food uses and innovative applications}

\subsection{Biofuels}

The composition of camelina oil allows its use as biofuel, either converted to biodiesel or directly as vegetable oil (Paulsen 2011). Methyl ester from camelina oil has been demonstrated to have characteristics similar to those of oilseed rape (Fröhlich and Rice 2005). When compared with mineral diesel fuel, camelina biodiesel shows a better performance in terms of power, a $50 \%$ reduction of visual smoke and $\mathrm{CO}$ emissions, and lower emissions of toxic components from gases, e.g., NOx (Bernardo et al. 2003; Lebedevas et al. 2012). Furthermore, biodiesel produced from camelina has a better environmental performance than soybean and oilseed rape when land use change impacts are considered (Bacenetti et al. 2017; Ciubota-Rosie et al. 2013). Notwithstanding these properties, the use of camelina oil as biodiesel still shows many drawbacks. Indeed, camelina methyl ester possesses a high iodine value, high CCR (Conradson carbon residue) values, high CFPP (Cloud Filter Pour Point), and low oxidation stability (Ciubota-Rosie et al. 2013; Karčauskiene et al. 2014; Zaleckas et al. 2012). Standards for iodine value have been demonstrated to be met by mixtures containing $50 \%$ camelina seed oil and $50 \%$ pork lard or by compositions consisting of $60 \%$ camelina oil and $40 \%$ exhausted frying oil (Karčauskiene et al. 2014; Zaleckas et al. 2012), while oxidation stability could be adjusted by adding an industrial anti-oxidant, e.g., ionol (Karčauskiene et al. 2014; Zaleckas et al. 2012). Therefore, improvement of camelina oil in terms of reducing its high degree of unsaturation and its molecular weight would be the pivotal point for its possible use as biodiesel fuel. Another possible use of camelina in biofuel production could derive from the valorization of residual straw by means of fast pyrolysis to produce biodiesel or hydrotreated vegetable oil. Both thermal and catalytic pyrolysis have been investigated by Hernando et al. (2017), showing the potential of both technologies to produce bio-oils from camelina residual biomass with different chemical characteristics.

\subsection{Hydraulic fluids and biopolymers}

In relation to the high amount of PUFAs, the production of epoxidized camelina oil has potential industrial applications in the field of adhesives, coatings, and resins (Kim et al. 2015). Unfortunately, European studies on this topic are negligible in comparison with those from the USA or Far East countries (i.e., the USA, China, Korea). A study by Kasetaite et al. (2014), comparing the performance of camelina oil-based polymers with the performance of linseed oil, demonstrated the valuable potential of camelina oil as a starting point for biopolymer synthesis. Additional studies on the use of camelina oil to produce polymeric materials have been carried out by Balanuca et al. (2014 and 2015) with the scope of characterizing these new products in comparison with reference petrol-based products. The results were optimistic for producing interpenetrating polymer networks (Balanuca et al. 2014), monomers for photopolymerization procedures (Balanuca et al. 2015), and nanocomposites (Balanuca et al. 2017), but camelina oil needs to be blended with other compounds in the formulation to achieve performance similar to petrol-based products. Polyhydroxyalkanoates (PHAs) are biodegradable polyesters synthesized by prokaryotes, which in the case of Pseudomonas sp. are able to provide high yields when supplemented by camelina oil (Bustamante et al. 2019). Camelina oil has also been reported as a valuable ingredient, with improved stability comparable to flax oil, in the formulation of chitosan films for food packaging, being able to promote thermal stability, anti-oxidative, anti-quorum sensing, and antimicrobial activity in the film (Gursoy et al. 2018). In the framework of the European project COSMOS, one of the possible end-uses of explored camelina oil was the formulation of lubricants (Labanauskas et al. 2017). In the reported study, only the monounsaturated fatty acid eicosenoic acid (C20:1) derived from camelina oil was considered a suitable feedstock for lubricant formulation.

The protein fraction of camelina seed has been successfully used to produce biobased adhesives (Liu et al. 2018), but unfortunately, in this field, European studies are completely lacking, highlighting a need for further research. 


\subsection{Feed}

Camelina oil and meal can be used as ingredients in livestock feed diets (Taranu et al. 2014) due to their high protein content, specific amino acid profile, and interesting energetic value (Colombini et al. 2014). The addition of camelina meal to the diets of rabbits (Oryctolagus cuniculus) and broiler chickens (Gallus gallus) has no effect on their growth performance and proportions, but it can modulate their FA profile (Zając et al. 2020). In fact, the meat produced was characterized by a lower content of saturated fatty acids (SFAs), lower monounsaturated fatty acids (MUFAs), and a higher content of $\omega-3$ PUFAs with a consequently decreased $\omega-6$ to $\omega-3$ PUFA ratio (Orczewska-Dudek and Pietras 2019; Peiretti et al. 2007). The possibility of including camelina meal in laying hen diets to improve PUFA content in yolks is not only widely reported in the literature (Aziza et al. 2013; Rokka et al. 2002) but also commercially scaled up in Europe (https://uovapascolo.it/). Camelina meal is more palatable than flax meal for laying hens, and the quality properties of the eggs and the eggshells are better (Cherian and Quezada 2016; Lolli et al. 2020; Rokka et al. 2002). Regarding milk production, the inclusion of camelina meal in the feeding of ewes (Ovis aries) and ruminants allows the production of lowsaturated milk with an increased content of PUFAs (Colombini et al. 2014; Halmemies-Beauchet-Filleau et al. 2017; Halmemies-Beauchet-Filleau et al. 2018; SzumacherStrabel et al. 2011). Nonetheless, the presence of antinutritional factors such as glucosinolates, phytic acid, sinapine, and condensed tannins represents an obstacle to the increase in the inclusion rate in animal rations (Colombini et al. 2014).

Aquaculture systems are often identified as unsustainable from an environmental point of view, and the replacement of fish oil with camelina oil will permit the improvement of this aspect without clear drawbacks in fish health and performance (Bell et al. 2010; Hixson et al. 2014a; Morais et al. 2012). Studies on the use of camelina oil, alone or in a mix, as a substitute for fish oil are reported in many cold-water fish species, i.e., Atlantic salmon (Salmo salar), Atlantic cod (Gadus morhua), and rainbow trout (Oncorhynchus mykiss) (Hixson et al. 2014b; Morais et al. 2012). Furthermore, in Europe, research on the possibility of replacing fish oil with transgenic camelina oil enriched with long-chain PUFAs (EPA and DHA) has also been carried out with promising results (Betancor et al. 2016, 2017), but the actual European regulation on the use of genetically modified organisms (GMOs) is completely limiting this application on any commercial scale.

Due to the large interest in the use of insects in animal feed, camelina cake has recently been tested in the formulation of a black soldier fly diet (Hermetia illucens) with promising results (http://cosmos-h2020.eu/media/2019/09/19-08-30COSMOS_Project_achievements_web.pdf).

\subsection{Cosmetics}

Vegetable oils have a major application in the cosmetic industry, especially now that consumers have become more interested in buying "Clean Beauty" (de Clermont-Gallerande 2020), leading to a $75 \%$ increase in "natural" raw material claims in the make-up market (Goodsitt 2019).

The high levels of anti-oxidant activity (Quéro et al. 2016) shown by camelina oil allow its use in various cosmetic formulations (Ionescu et al. 2015). Many commercial cosmetic products containing camelina oil in their formulation such as facial and body creams, shampoos, and other hair care products already exist, but almost nothing is published in the reviewed scientific literature. Nevertheless, in the framework of the COSMOS project, different molecules to be used in fragrances for cosmetic formulation were obtained from fatty acids derived from refined camelina oil by Arkema (France, http://cosmos-h2020.eu/media/2017/10/COSMOS-D6.1List-of-molecules-that-can-be-used-for-flavors-andfragrances.pdf). Despite not being already in the market, these molecules could represent valuable coproducts for increasing the economic sustainability of the whole camelina value chain.

\section{Genetic diversity and breeding strategies}

Archeological findings of camelina in the central and eastern parts of Europe date from the late Neolithic and early Bronze Ages (Bouby 1998). Southeast Europe and Southwest Asia are believed to be the center of the origin of camelina, even if one study evoked the Russian-Ukrainian area as a camelina genetic diversity hotspot (Ghamkhar et al. 2010). In these native regions, camelina could be found both cultivated or as a weed, but the increasing use of herbicides over time has decreased the presence of wild camelina in cultivated fields (Brock et al. 2018). Wild camelina may represent a valuable source of genetic diversity for this species in future breeding programs in Europe. The allohexaploid genome of camelina is sequenced and embraces approximately 788.6 MB, containing approximately three times more genes than Arabidopsis thaliana and with the highest genetic density among sequenced plant genomes (Chaudhary et al. 2020; Kagale et al. 2016). Even though it has a sequenced genome, information on camelina genes controlling important traits is still lacking.

The number of available camelina accessions is nearly 1000. There are 799 accessions stored within the EURISCO (European Search Catalog for Plant Genetic Resources) collection, 137 in PGRC (Plant Gene Resources of Canada), and 49 deposited in the USDA National Plant Germplasm System. Genetic studies conducted on camelina included a small number of accessions (Gehringer et al. 2006; Ghamkhar et al. 2010; Kim et al. 2017; Manca et al. 2013; Vollmann et al. 
2005) using a modest number of DNA molecular markers. Vollmann (2005) found that $2 / 3$ of analyzed RAPDs (Random Amplified Polymorphic DNA) were polymorphic, amplifying only one to three loci per marker, imposing a low level of genetic diversity in camelina. Genotyping-bysequencing is an efficient method for SNP discovery, and generated data can be used together with a phenotyping approach to analyze marker-trait associations (Luo et al. 2019). Using the SNP marker technology, Kim et al. (2017) identified marker-trait links for plant height, leaf length, and silicle size. To make use of these molecular marker systems in marker-assisted selection and thus accelerate the breeding process, both greater mapping populations and numbers of molecular markers are required.

Flowers of camelina are self-pollinated with a low level of outcrossing. The most commonly used breeding procedure in camelina is pure line selection, after which pedigree or bulk breeding methods are used for segregating generations (Vollmann and Eynck 2015). Furthermore, the single seed descent method is used for the rapid development of recombinant inbred lines (Gehringer et al. 2006). The efficiency of double-haploid technology, the fastest procedure of producing homozygous lines, in camelina is rather low (Ferrie and Bethune 2011). Mutagenesis, as a way of introducing genetic variability, is a frequent companion in camelina breeding, especially aiming at a desirable fatty acid composition.

As a niche crop, camelina has not been subjected to intensive breeding procedures, meaning there is a vast scope to explore its genetic potential. Breeding for high oil content is one of the major breeding goals of camelina. Oil content is a polygenic trait influenced mainly by the environment. Both oil and fatty acid contents are sensitive to temperature during the phase of seed filling. Camelina has a relatively high oil content, ranging from 28 to $49 \%$ of the total seed weight, and is rich in essential fatty acids. Camelina has high levels of unsaturated $\alpha$-linolenic (30-36\%) and eicosenoic acid (15$20 \%$ ). Since flax is the main source of omega-3 fatty acids, camelina represents an excellent alternative to this type of oil.

Market requests have guided breeding strategies on altered fatty acid content and composition in vegetable oils. To comply with industrial demands for high content of single fatty acids for non-food uses, in particular high ALA, a mutagenesis-based breeding program was initiated in Germany (Büchsenschütz-Nothdurft et al. 1998). The authors used ethyl methanesulfonate (EMS), a mutagenic chemical that causes random mutations via nucleotide substitution in the genome. Camelina can easily be genetically transformed with Agrobacterium tumefaciens (Sitther et al. 2018) to produce oil with increased levels of oleic acid and decreased contents of LA and ALA fatty acids (Yuan and Li 2020). Similarly, delta-12 fatty acid desaturase (FAD2) suppression by a system made of clustered regularly interspaced short palindromic repeats coupled with protein Cas9 (CRISPR/
Cas9) (Jiang et al. 2017) leads to an increase in oleic acid content from 16 to $\geq 50 \%$ (Jiang et al. 2017). After EMS treatment of camelina, seed mutant lines with altered fatty acid composition can be detected, which offers an opportunity to target genes of interest via CRISPR/Cas9 technology. Ozseyhan's team managed to decrease very long-chain fatty acid (VLCFA) seed content by $60 \%$ by inducing mutations in fatty acid elongase 1 (FAE1 9) genes (Ozseyhan et al. 2018). When reducing VLCFA levels, the levels of other fatty acids increase. Thus, it is possible to create a breeding material that has a favorable ALA content for food use. In recent years, in the UK, transgenic camelina was engineered to produce $\omega-3$ long chain polyunsaturated with five gene assemblies containing genes from microalgae for eicosapentaenoic acid (EPA) production (Ruiz-Lopez et al. 2014). In 2014, the UK government allowed the first field trials with transgenic camelina. This camelina line contained high levels of DHA (docosahexaenoic acid) and EPA, $\omega-3$ acids typically found in fish oil. The use of genetically modified (GM) camelina in fish feeding has the potential to make fish farming more sustainable. After consuming food containing either commercial blended fish oil or oil from GM camelina, there was no difference in DHA and EPA incorporation into the blood lipids of humans (West et al. 2019). Synthesis of acetyltriacylglycerols (Liu et al. 2015, b) and $\omega-7$ fatty acids (Nguyen et al. 2015) represent other examples of metabolic pathway alterations in transgenic camelina.

Camelina seed size is one of the traits related to yield that needs to be improved. Its seed is quite small, approximately $1.5 \mathrm{~mm} \times 0.8 \mathrm{~mm}$. Having larger seeds would mean stronger vigor, even emergence and seedling establishment in the field, which would enhance camelina planting and facilitate harvesting. A recent study showed that seed size rose after starch biosynthesis suppression ( $\mathrm{Na}$ et al. 2018). However, the amount of oil in seeds remained the same, while seed weight rose due to increased protein content ( $\mathrm{Na}$ et al. 2018). Hence, there is a need for further research into mechanisms that will concurrently increase both seed size and oil content.

The European Union's (EU) need for oil is high and increasing, with a net import of 86.7\% in 2017 (Eurostat 2017). Oil prices largely oscillate, causing economic instability and repressing economic advancement. Many European countries, especially Eastern Europe, consider only one or two oil sources. The diversification of energy supply and decreasing energy import dependence are part of the European Union's strategy (European Council 2015). To fulfill EU ambitions and diminish dependence on imports, the use of new alternative sources of edible oils with stable quality and competitive price will become compulsory for the near future.

In EU, scientific research on GMO crops can be conducted under confined conditions, while growing in open fields is still restricted due to environmental and biodiversity concerns. In terms of legislation, the CRISPR/Cas9 editing technique is 
considered a process-based tool that uses foreign genes during mutation induction within organisms. Mutagenesis and cell fusion of plant cells of organisms that can exchange their DNA via traditional breeding techniques are excluded from the EU Directive 2001/18/EC. Since 2018, the Court of Justice of the EU elucidated in a ruling (Case C-528/16) that organisms derived from new techniques of mutagenesis are considered GMOs and thus regulated within the legal framework of EU GMO legislation (Judgment of the Court 2018). Most likely, it is a matter of time when society will get used to these novel tools that can be safely exploited among others to prevent human, animal, and plant diseases.

\section{Strengths, weaknesses, opportunities, and threats (SWOT) of camelina in Europe}

Despite the wide interest witnessed by the active European literature on camelina, this crop is still a niche oilseed species. Otherwise, as highlighted in the present review, camelina possesses many of the relevant features to become a "real crop" since it is able to meet the requirements of the different actors along the value chain, presenting unique agronomic characteristics, multiple end-uses, and good adaptability to all European climates and soils. Camelina still has some weaknesses to be overcome before becoming a widespread European crop. For this reason, the authors decided to summarize the outcomes of the present review study in a simplified SWOT analysis, which is reported in Fig. 2. Together with undeniable strengths linked to both agronomic characteristics and seed compositional peculiarities, camelina still presents some bottlenecks mainly linked to a poorly defined market for all its seed fractions. Compared with the two most widely cultivated oilseed crops in Europe, oilseed rape and sunflower, camelina has some indisputable advantages. In particular, in comparison with oilseed rape, camelina has considerably lower input requirements in terms of both fertilizers and chemicals, lower shattering losses, and shorter crop cycles. Otherwise, when compared with sunflower, autumnsown camelina could represent a feasible alternative in areas where spring sunflower is highly suffering from heat and drought stress, as in central and southern Spain. However, the market drives prices and, consequently, the economic revenues of farmers, who might be very interested in growing camelina for agronomic and ecosystem-related aspects, but a stable market price will be compulsory in the next development step of the camelina value chain in Europe.

\section{Conclusions}

Certainly, not even in the rosiest future will camelina ever replace oilseed rape or sunflower, but hopefully, it will become an interesting alternative to be included in European
Fig. 2 SWOT analysis of camelina in Europe

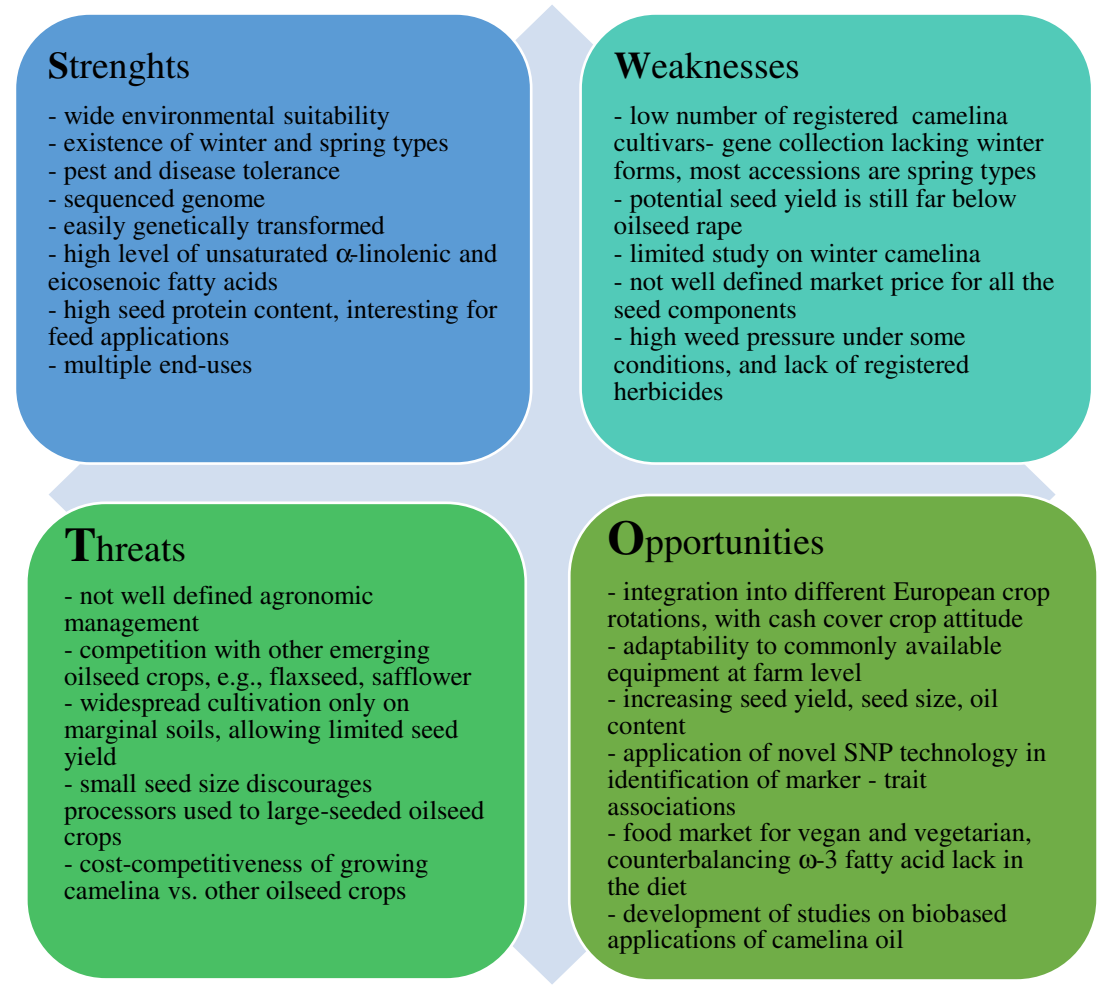


agricultural systems, being able to sustainably intensify agricultural systems and to provide farmers with additional choices for their rotation schemes. Among the multiple enduses of camelina-derived products, for sure, the application in animal feed is now representing the driving force for its stable introduction and diffusion in Europe, in relation to the tremendous lack of protein for animal feed. Furthermore, camelina seed is a valuable source of natural anti-oxidants, especially tocopherols, phenolic acids, and flavonoids, and its oil, particularly high in $\omega-3$ PUFAs, will soon represent a healthy choice to be included in European diet. The ability of camelina to be transformed into a species with completely a different fatty acid content and composition makes it an ideal candidate for the production of particular fatty acids for inclusion in the human diet, livestock and aquaculture feed, and biobased products. The ability to manage its fatty acid composition connected with its weak outcrossing potential makes camelina a notable crop for sustainable oil biosynthesis without affecting the production of staple food crops, thus avoiding the usual food vs. non-food debate.

\section{Compliance with ethical standards}

Funding Open access funding provided by Alma Mater Studiorum Università di Bologna within the CRUI-CARE Agreement. This research was supported by the MAGIC project, which has received funding from the European Union's Horizon 2020 research and innovation program under grant agreement no. 727698 (paragraph 3: Sustainable cultivation strategies for Europe); the ARGENTO project, which has received funding from the Italian Research Projects of Relevant National Interest - Announcement 2017 Prot. 2017LZ3CHF the PRIN 2017 (paragraph 5: Non-food uses and innovative applications); the Ministry of Education, Science and Technological Development of the Republic of Serbia, grant number: 451-03-68/2020-14/200032 (paragraph 4: Seed qualitative traits and food uses; and paragraph 6: Genetic diversity and breeding strategies).

Conflict of interest The authors declare that they have no conflict of interest.

Authors' contribution Conceptualization: F.Z.; writing-original draft: F.Z., B.A., A.M.J., N.G., D.R., and B.K.; writing - review and editing: F.Z., B.A., A.M.J., D.R., B.K., and A.M.; funding acquisition: A.M.J. and A.M.; visualization: B.A. and B.K.; supervision, A.M.

Data availability Data sharing is not applicable to this article as no datasets were generated or analyzed during the current study.

Open Access This article is licensed under a Creative Commons Attribution 4.0 International License, which permits use, sharing, adaptation, distribution and reproduction in any medium or format, as long as you give appropriate credit to the original author(s) and the source, provide a link to the Creative Commons licence, and indicate if changes were made. The images or other third party material in this article are included in the article's Creative Commons licence, unless indicated otherwise in a credit line to the material. If material is not included in the article's Creative Commons licence and your intended use is not permitted by statutory regulation or exceeds the permitted use, you will need to obtain permission directly from the copyright holder. To view a copy of this licence, visit http://creativecommons.org/licenses/by/4.0/.

\section{References}

Abramovic H, Abram V (2005) Physico-chemical properties, composition and oxidative stability of Camelina sativa oil. Food Technol Biotechnol 43(1):63-70

Abramovič H, Butinar B, Nikolič V (2007) Changes occurring in phenolic content, tocopherol composition and oxidative stability of Camelina sativa oil during storage. Food Chem 104(3):903-909. https://doi.org/10.1016/j.foodchem.2006.12.044

Acharya K, Yan G, Berti M (2019) Can winter camelina, crambe, and brown mustard reduce soybean cyst nematode populations? Ind Crop Prod 140:111637. https://doi.org/10.1016/j.indcrop.2019. 111637

Adeux G, Munier-Jolain N, Meunier D, Farcy P, Carlesi S, Barberi P, Cordeau S (2019) Diversified grain-based cropping systems provide long-term weed control while limiting herbicide use and yield losses. Agron Sustain Dev 39:42. https://doi.org/10.1007/s13593019-0587-X

Angelini LG, Moscheni E, Colonna G, Belloni P, Bonari E (1997) Variation in agronomic characteristics and seed oil composition of new oilseed crops in Central Italy. Ind Crop Prod 6(3-4):313-323. https://doi.org/10.1016/S0926-6690(97)00022-8

Arnold C, Konkel A, Fischer R, Schunck WH (2010) Cytochrome P450dependent metabolism of $\omega-6$ and $\omega-3$ long-chain polyunsaturated fatty acids. Pharmacol Rep 62(3):536-547. https://doi.org/10.1016/ s1734-1140(10)70311-x

Aziza AE, Panda AK, Quezada N, Cherian G (2013) Nutrient digestibility, egg quality, and fatty acid composition of brown laying hens fed camelina or flaxseed meal. J Appl Poult Res 22(4):832-841. https:// doi.org/10.3382/japr.2013-00735

Aziza AE, Quezada N, Cherian G (2010) Feeding Camelina sativa meal to meat-type chickens: effect on production performance and tissue fatty acid composition. J Appl Poult Res 19(2):157-168. https://doi. org/10.3382/japr.2009-00100

Bacenetti J, Restuccia A, Schillaci G, Failla S (2017) Biodiesel production from unconventional oilseed crops (Linum usitatissimum $\mathrm{L}$. and Camelina sativa L.) in Mediterranean conditions: environmental sustainability assessment. Renew Energy 112:444-456. https://doi. org/10.1016/j.renene.2017.05.044

Baker EJ, Miles EA, Burdge GC, Yaqoob P, Calder PC (2016) Metabolism and functional effects of plant-derived omega-3 fatty acids in humans. Prog Lipid Res 64:30-56. https://doi.org/10. 1016/j.plipres.2016.07.002

Balanuca B, Lungu A, Conicov I, Stan R, Vasile E, Vuluga DM, Iovu H (2014) Novel bio-based IPNs obtained by simultaneous thermal polymerization of flexible methacrylate network based on a vegetable oil and a rigid epoxy. Polym Adv Technol 26:19-25. https://doi. org/10.1002/pat.3413

Balanuca B, Stan R, Hanganu A, Lungu A, Iovu H (2015) Design of new camelina oil-based hydrophilic monomers for novel polymeric materials. J Am Oil Chem Soc 92:881-891. https://doi.org/10.1007/ s11746-015-2654-Z

Balanuca B, Stan R, Lungu A, Vasile E, Iovu H (2017) Hybrid networks based on epoxidized camelina oil. Des Monomers Polym 20(1):10 17. https://doi.org/10.1080/15685551.2016.1231031

Bătrîna ȘL, Jurcoane Ș, Popescu I, Marin F, Imbrea IM, Crista F, Pop G, Imbrea F (2020) Camelina sativa: a study on amino acid content. Biotechnol Lett 25(1):1136-1142. https://doi.org/10.25083/rbl/25. 1/1136.1142

Bell JG, Pratoomyot J, Strachan F, Henderson RJ, Fontanillas R, Hebard A, Guy DR, Hunter D, Tocher DR (2010) Growth, flesh adiposity and fatty acid composition of Atlantic salmon (Salmo salar) families with contrasting flesh adiposity: effects of replacement of dietary 
fish oil with vegetable oils. Aquaculture 306:225-232. https://doi. org/10.1016/j.aquaculture.2010.05.021

Bernardo A, Howard-Hidige R, O'Connel A, Nichol R, Ryan J, Rice B, Roche E, Leahy JJ (2003) Camelina oil as a fuel for diesel transport engines. Ind Crop Prod 17(3):191-197. https://doi.org/10.1016/ S0926-6690(02)00098-5

Berti M, Gesch R, Eynck C, Anderson J, Cermak S (2016) Camelina uses, genetics, genomics, production, and management. Ind Crop Prod 94:690-697. https://doi.org/10.1016/j.indcrop.2016.09.034

Berti M, Gesch R, Johnson B, Ji Y, Seames W, Aponte A (2015) Doubleand relay-cropping of energy crops in the northern Great Plains, USA. Ind Crop Prod 75:26-34. https://doi.org/10.1016/j.indcrop. 2015.05.012

Betancor MB, Li K, Sprague M, Bardal T, Sayanova O, Usher S, Han L, Måsøval K, Torrissen O, Napier JA, Tocher DR, Olsen RE (2017) An oil containing EPA and DHA from transgenic Camelina sativa to replace marine fish oil in feeds for Atlantic salmon (Salmo salar L.): effects on intestinal transcriptome, histology, tissue fatty acid profiles and plasma biochemistry. PLoS One 12(4):e0175415. https://doi.org/10.1371/journal.pone.0175415

Betancor MB, Sprague M, Montero D, Usher S, Sayanova O, Campbell PJ, Napier JA, Caballero MJ, Izquierdo M, Tocher DR (2016) Replacement of marine fish oil with de novo omega-3 oils from transgenic Camelina sativa in feeds for gilthead sea bream (Sparus aurata L.). Lipids 51(10):1171-1191. https://doi.org/10.1007/ s11745-016-4191-4

Bilalis D, Roussis I, Fuentes F, Kakabouki I, Travlos I (2017) Organic agriculture and innovative crops under Mediterranean conditions. Not Bot Horti Agrobo 45(2):323-331. https://doi.org/10.15835/ nbha45210867

Blackshaw RE, Johnson EN, Gan Y, May WE, McAndrew DW, Barthet V, McDonald T, Wispinski D (2011) Alternative oilseed crops for biodiesel feedstock on the Canadian prairies. Can J Plant Sci 91(5): 889-896. https://doi.org/10.4141/cjps2011-002

Bouby L (1998) Two early finds of gold-of-pleasure (Camelina sp.) in middle Neolithic and Chalcolithic sites in western France. Antiquity 72(276):391-398. https://doi.org/10.1017/S0003598X0008666X

Brock JR, Dönmez AA, Beilstein MA, Olsen KM (2018) Phylogenetics of Camelina Crantz. (Brassicaceae) and insights on the origin of gold-of-pleasure (Camelina sativa). MoPhylogenet Evol 127:834 842. https://doi.org/10.1016/j.ympev.2018.06.031

Büchsenschütz-Nothdurft A, Schuster A, Friedt W (1998) Breeding for modified fatty acid composition via experimental mutagenesis in Camelina sativa (L.) Crantz. Ind Crop Prod 7(2-3):291-295. https://doi.org/10.1016/S0926-6690(97)00060-5

Budin JT, Breene WM, Putnam DH (1995) Some compositional properties of camelina (Camelina sativa L. Crantz) seeds and oils. J Am Oil Chem Soc 72(3):309-315. https://doi.org/10.1007/BF02541088

Bustamante D, Tortajada M, Ramon D, Rojas A (2019) Camelina oil as a promising substrate for mcl-pha production in Pseudomonas sp. cultures. Appl. Food Biotechnol 6(1):61-70. https://doi.org/10. 22037/afb.v6i1.21635

Carton N, Carlsson G, Jensen ES, Corre-Hellou G (2020) Intercropping of lupin for weed control and complementary grain production in organic farming. https://zenodo.org/badge/DOI/10.5281/zenodo. 3741487.svg

Chaudhary R, Koh CS, Kagale S, Tang L, Wu SW, Lv Z, Mason AS, Sharpe AG, Diederichsen A, Parkin IAP (2020) Assessing diversity in the camelina genus provides insights into the genome structure of Camelina sativa. G3-Genes Genomes Genet 10:1297-1308. https:// doi.org/10.1534/g3.119.400957

Cherian G, Campbell A, Parker T (2009) Egg quality and lipid composition of eggs from hens fed Camelina sativa. J Appl Poult Res 18(2): 143-150. https://doi.org/10.3382/japr.2008-00070

Cherian G, Quezada N (2016) Egg quality, fatty acid composition and immunoglobulin $\mathrm{Y}$ content in eggs from laying hens fed full fat camelina or flax seed. J Anim Sci Biotechnol 7:15. https://doi.org/ 10.1186/s40104-016-0075-y

Christou M, Alexopoulou E, Zanetti F, Krzyżaniak M, Stolarski M, Righini D, Monti A (2018) Sowing dates effect on Camelina growth in different EU climatic zones. In proceedings of $26^{\text {th }}$ European Biomass Conference and Exhibition. May 2018:133-135. https:// doi.org/10.5071/26thEUBCE2018-1CO.5.3

Ciubota-Rosie C, Ruiz JR, Ramos MJ, Pérez Á (2013) Biodiesel from Camelina sativa: a comprehensive characterisation. Fuel 103:572577. https://doi.org/10.1016/j.fuel.2012.09.062

Colombini S, Broderick GA, Galasso I, Martinelli T, Rapetti L, Russo R, Reggiani R (2014) Evaluation of Camelina sativa (L.) Crantz meal as an alternative protein source in ruminant rations. J Sci Food Agric. https://doi.org/10.1002/jsfa.6408

Constantin J, Le Bas C, Justes E (2015) Large-scale assessment of optimal emergence and destruction dates for cover crops to reduce nitrate leaching in temperate conditions using the STICS soil-crop model. Eur J Agron 69:75-87. https://doi.org/10.1016/j.eja.2015. 06.002

Cunnane S (2004) Recommendations for intakes of polyunsaturated fatty acids in healthy adults. ISSFAL Newslett 11:12-25

Czarnik M, Jarecki W, Bobrecka-Jamro D (2017) The effects of varied plant density and nitrogen fertilization on quantity and quality yield of Camelina Sativa L. Emir J Food Agr 29(12):988-993. https://doi. org/10.9755/ejfa.2017.v29.112.1569

Czarnik M, Jarecki W, Bobrecka-Jamro D (2018) Reaction of winter varieties of false flax (Camelina sativa (L.) Crantz) to the varied sowing time. J Cent Eur Agric 19(3):571-586. https://doi.org/10. 5513/JCEA01/19.3.2054

de Clermont-Gallerande H (2020) Functional roles of lipids in make-up products. OCL 27:33. https://doi.org/10.1051/ocl/2020026

De Lorgeril M, Renaud S, Salen P, Monjaud I, Mamelle N, Martin JL, Monjaud I, Guidollet J, Touboul P, Delaye J (1994) Mediterranean alpha-linolenic acid-rich diet in secondary prevention of coronary heart disease. Lancet 343(8911):1454-1459. https://doi.org/10. 1016/S0140-6736(94)92580-1

Eidhin DN, Burke J, O'Beirne D (2003) Oxidative stability of w3-rich camelina oil and camelina oil-based spread compared with plant and fish oils and sunflower spread. J Food Sci 68(1):345-353. https:// doi.org/10.1111/j.1365-2621.2003.tb14163.x

European Council (2015) Council Conclusions of March 2015 (http:// www.eesc.europa.eu/resources/docs/european-council-conclusions19-20-march-2015-en.pdf) (03 October 2017)

Eurostat (2017) Oil and petroleum products - a statistical overview. Retrieved from ec.europa.eu/eurostat, last assess 22.10.2019

Fabre JF, Lacroux E, Gravé G, Mouloungui Z (2020) Extraction of camelina mucilage with ultrasound and high flow rate fluid circulation. Ind Crop Prod 144:112057. https://doi.org/10.1016/j.indcrop. 2019.112057

Faustino AR, Osorio NM, Tecelão C, Canet A, Valero F, Ferreira-Dias S (2016) Camelina oil as a source of polyunsaturated fatty acids for the production of human milk fat substitutes catalyzed by a heterologous Rhizopus oryzae lipase. Eur J Lipid Sci Technol 118(4):532544. https://doi.org/10.1002/ejlt.201500003

Ferrie AMR, Bethune TD (2011) A microspore embryogenesis protocol for Camelina sativa, a multi-use crop. Plant Cell Tissue Organ 106(3):495-501. https://doi.org/10.1007/s11240-011-9948-0

Fröhlich A, Rice B (2005) Evaluation of Camelina sativa oil as a feedstock for biodiesel production. Ind Crop Prod 21(1):25-31. https:// doi.org/10.1016/j.indcrop.2003.12.004

Gaba S, Lescourret F, Boudsocq S, Enjalbert J, Hinsinger P, Journet EP, Navas ML, Wery J, Louarn G, Malezieux E, Pelzer E, Prudent M, Ozier-Lafontaine H (2015) Multiple cropping systems as drivers for providing multiple ecosystem services: from concepts to design. Agron Sustain Dev 35:607-623. https://doi.org/10.1007/s13593014-0272-z 
Gehringer A, Friedt W, Luehs W, Snowdon RJ (2006) Genetic mapping of agronomic traits in false flax (Camelina sativa subsp sativa). Genome 49(12):1555-1563. https://doi.org/10.1139/g06-117

Gesch RW, Archer DW, Berti MT (2014) Dual cropping winter camelina with soybean in the northern corn belt. Agron J 106:1735-1745. https://doi.org/10.2134/agronj14.0215

Ghamkhar K, Croser J, Aryamanesh N, Campbell M, Kon'kova N, Francis C (2010) Camelina (Camelina sativa L.) Crantz as an alternative oilseed: molecular and ecogeographic analyses. Genome 53(7):558-567. https://doi.org/10.1139/G10-034

Global Organisation for EPA and DHA (GOED) (2014) Global recommendations for EPA and DHA intake

Gollner G, Gabler C, Grausgruber-Gröger S, Friedel JK, Grausgruber H, Freyer B (2010) Grain legumes in mixed stands with false flax (Camelina sativa) in organic farming under Pannonian site conditions. J Kult 62(11):402-408

Goodsitt L (2019) The future of color cosmetics. Global annual review: what's now and what's next for the colour cosmetics market Available from https://clients.mintel.com/report/the-future-ofcolour-cosmetics-2019? fromSearch $=\% 3$ Ffilters.category $\% 3 \mathrm{D} 2 \%$ 26last_filter\%3Dcategory

Groeneveld JH, Klein AM (2013) Pollination of two oil-producing plant species: camelina (Camelina sativa L. Crantz) and pennycress (Thlaspi arvense L.) double-cropping in Germany. GCB Bioenergy 6(3). https://doi.org/10.1111/gcbb.12122

Gursoy M, Sargin I, Mujtaba M, Akyuz B, Ilk S, Akyuz L, Kaya M, Cakmak YS, Salaberria AM, Labidi J, Erdem N (2018) False flax (Camelina sativa) seed oil as suitable ingredient for the enhancement of physicochemical and biological properties of chitosan films. Int J Biol Macromol 114:1224-1232. https://doi.org/10.1016/j. ijbiomac.2018.04.029

Halmemies-Beauchet-Filleau A, Rinne M, Lamminen M, Mapato C, Ampapon T, Wanapat M, Vanhatalo A (2018) Review: alternative and novel feeds for ruminants: nutritive value, product quality and environmental aspects. Animal 12(S2):295-309. https://doi.org/10. 1017/S1751731118002252

Halmemies-Beauchet-Filleau A, Shingfield KJ, Simpura I, Kokkonen T, Jaakkola S, Toivonen V, Vanhatalo A (2017) Effect of incremental amounts of camelina oil on milk fatty acid composition in lactating cows fed diets based on a mixture of grass and red clover silage and concentrates containing camelina expeller. J Dairy Sci 100:305324. https://doi.org/10.3168/jds.2016-11438

Hernando H, Fermoso J, Moreno I, Coronado JM, Serrano DP, Pizarro P (2017) Thermochemical valorization of camelina straw waste via fast pyrolysis. Biomass Conv Bioref 7:277-287. https://doi.org/10. 1007/s13399-017-0262-x

Hixson SM, Parrish CC, Anderson DM (2014a) Full substitution of fish oil with camelina (Camelina sativa) oil, with partial substitution of fish meal with camelina meal, in diets for farmed Atlantic salmon (Salmo salar) and its effect on tissue lipids and sensory quality. Food Chem 157:51-61. https://doi.org/10.1016/j.foodchem.2014. 02.026

Hixson SM, Parrish CC, Anderson DM (2014b) Changes in tissue lipid and fatty acid composition of farmed rainbow trout in response to dietary camelina oil as a replacement of fish oil. Lipids 49(1):97111. https://doi.org/10.1007/s11745-013-3862-7

Hrastar R, Abramovič H, Košir IJ (2012) In situ quality evaluation of Camelina Sativa landrace. Eur J Lipid Sci Technol 114(3):343-351. https://doi.org/10.1002/ejlt.201100003

Ibrahim FM, El Habbasha SF (2015) Chemical composition, medicinal impacts and cultivation of Camelina (Camelina sativa). Int $\mathrm{J}$ Pharmtech Res 8(10):114-122

Ionescu N, Ivopol GC, Neagu M, Popescu M, Meghea A (2015) Fatty acids and antioxidant activity in vegetable oils used in cosmetic formulations. UPB Sci Bull Ser B 77(3)
Jankowski KJ, Sokólski M, Kordan B (2019) Camelina: yield and quality response to nitrogen and sulfur fertilization in Poland. Ind Crop Prod 141:111776. https://doi.org/10.1016/j.indcrop.2019.111776

Jiang WZ, Henry IM, Lynagh PG, Comai L, Cahoon EB, Weeks DP (2017) Significant enhancement of fatty acid composition in seeds of the allohexaploid, Camelina sativa, using CRISPR/Cas9 gene editing. Plant Biotechnol J 15(5):648-657. https://doi.org/10.1111/ pbi. 1266

Judgement of the Court (Grand Chamber), 25 July 2018 in Case C-528/ 16. http://curia.europa.eu/juris/document/document.jsf;jsessionid= 9 ea 7 d 0 f $130 \mathrm{dcd} 5 \mathrm{adc} 6577 \mathrm{ba} 74 \mathrm{dc} 9 \mathrm{~b} 5 \mathrm{acf} 2530 \mathrm{~b} 87 \mathrm{e} 485$. e $34 \mathrm{KaxiLc} 3 \mathrm{eQc} 40 \mathrm{LaxqMbN} 4 \mathrm{~Pb} 3$ ye 0 ?text $=\&$ docid $=$ $204387 \&$ pageIndex $=0 \&$ doclang $=E N \&$ mode $=$ req $\&$ dir $=\& o c c=$ first\&part=1\&cid=72898. Accessed 24 Oct 2019

Jurcoane S, Dobre P, Florea C, Petre SM, Ropota M (2011) Camelina sativa-a useful plant source for renewable jet fuels, human nutrition and animal feed. Proceeding Simpozion National editia Xia Plante medicinale -prezent si perspective, Piatra Neamt, Romania, 9-10 June 2011, 33-34

Kagale S, Nixon J, Khedikar Y, Pasha A, Provart NJ, Clarke WE, Bollina V, Robinson SJ, Coutu C, Hegedus DD, Sharpe AG, Parkin IAP (2016) The developmental transcriptome atlas of the biofuel crop Camelina sativa. Plant J 88:879-894. https://doi.org/10.1111/tpj. 13302

Karčauskiene D, Sendžikiene E, Makarevičiene V, Zaleckas E, Repšiene R, Ambrazaitiene D (2014) False flax (Camelina sativa L.) as an alternative source for biodiesel production. Zemdirbyste 101 (2): 161-168. 10.13080/z-a.2014.101.021

Kasetaite S, Ostrauskaite J, Grazuleviciene V, Svediene J, Bridziuviene D (2014) Camelina oil- and linseed oil-based polymers with bisphosphonate crosslinks. J Appl Polym Sci 40683:1-8. https://doi.org/10. 1002/app.40683

Katar D (2013) Determination of fatty acid composition on different false flax (Camelina sativa (L.) Crantz) genotypes under Ankara ecological conditions. Turk J Field Crops 18(1):66-72

Kim C, Lee JH, Chung YS, Choi SC, Guo H, Lee TH, Lee S (2017) Characterization of twenty Camelina spp. accessions using single nucleotide polymorphism genotyping. Hortic Environ Biotechnol 58(2):187-194. https://doi.org/10.1007/s13580-017-0264-4

Kim N, Li Y, Sun XS (2015) Epoxidation of Camelina sativa oil and peel adhesion properties. Ind Crop Prod 64:1-8. https://doi.org/10.1016/ j.indcrop.2014.10.025

Kirkhus B, Lundon AR, Haugen JE, Vogt G, Borge GI, Henriksen BI (2013) Effects of environmental factors on edible oil quality of organically grown Camelina Sativa. J Agric Food Chem 61(13): 3179-3185. https://doi.org/10.1021/jf304532u

Krzyżaniak M, Stolarski MJ, Tworkowski J, Puttick D, Eynck C, Załuski D, Kwiatkowski J (2019) Yield and seed composition of 10 spring camelina genotypes cultivated in the temperate climate of Central Europe. Ind Crop Prod 138:111443. https://doi.org/10.1016/j. indcrop.2019.06.006

Kurasiak-Popowska D, Graczyk M, Stuper-Szablewska K (2020) Winter camelina seeds as a raw material for the production of erucic acid free oil. Food Chem 330:127265. https://doi.org/10.1016/j. foodchem.2020.127265

Kurasiak-Popowska D, Ryńska B, Stuper-Szablewska K (2019) Analysis of distribution of selected bioactive compounds in Camelina sativa from seeds to pomace and oil. Agronomy 9(4):168. https://doi.org/ 10.3390/agronomy9040168

Kurasiak-Popowska D, Stuper-Szablewska K (2019) The phytochemical quality of Camelina sativa seed and oil. Acta Agric Scand Sect B Soil Plant Sci 70(1):39-47. https://doi.org/10.1080/09064710.2019. 1665706

Kurasiak-Popowska D, Tomkowiak A, Człopińska M, Bocianowski J, Weigt JD, Nawracała J (2018) Analysis of yield and genetic 
similarity of Polish and Ukrainian Camelina sativa genotypes. Ind Crop Prod 123:667-675. https://doi.org/10.1016/j.indcrop.2018.07. 001

Labanauskas L, Bražinskienė D, Strakšys A, Asadauskas S (2017) Suitability of basestocks from medium chain fatty acids for hydraulic fluids. In proceedings of BALTTRIB, Kaunas, Lithuania, 16-17 November 2017. 10.15544/balttrib.2017.16

Laviano A, Rianda S, Molfino A, Fanelli FR (2013) Omega-3 fatty acids in cancer. Curr Opin Clin Nutr Metab Care 16(2):156-161. https:// doi.org/10.1097/MCO.0b013e32835d2d99

Lebedevas S, Pukalskas S, Žaglinskis J, Matijošius J (2012) Comparative investigations into energetic and ecological parameters of camelinabased biofuel used in the $1 \mathrm{Z}$ diesel engine. Transport 27(2):171177. https://doi.org/10.3846/16484142.2012.694078

Leclère M, Jeuffroy MH, Butier A, Chatain C, Loyce C (2019) Controlling weeds in camelina with innovative herbicide-free crop management routes across various environments. Ind Crop Prod 140:111605. https://doi.org/10.1016/j.indcrop.2019.111605

Leclère M, Loyce C, Jeuffroy MH (2018) Growing camelina as a second crop in France: a participatory design approach to produce actionable knowledge. Eur J Agron 101:78-89. https://doi.org/10.1016/j. eja.2018.08.006

Li J, Huang L, Zhang J, Coulter JA, Li L (2019) Diversifying crop rotation improves system robustness. Agron Sustain Dev 39:38. https:// doi.org/10.1007/s13593-019-0584-0

Lin BB (2011) Resilience in agriculture through crop diversification: adaptive management for environmental change. Bioscience 61(3): 183-193. https://doi.org/10.1525/bio.2011.61.3.4

Liu H, Bean S, Sun XS (2018) Camelina protein adhesives enhanced by polyelectrolyte interaction for plywood applications. Ind Crop Prod 124:343-352. https://doi.org/10.1016/j.indcrop.2018.07.068

Liu J, Rice A, McGlew K, Shaw V, Park H, Clemente T, Pollard M, Ohlrogge J, Durrett TP (2015) Metabolic engineering of oilseed crops to produce high levels of novel acetyl glyceride oils with reduced viscosity, freezing point and calorific value. Plant Biotechnol J 13(6):858-865. https://doi.org/10.1111/pbi.12325

Liu J, Tjellström H, McGlew K, Shaw V, Rice A, Simpson J, Kosma D, Ma W, Yang W, Strawsine M, Cahoon E, Durret TP, Ohlrogge J (2015) Field production, purification and analysis of high-oleic acetyl-triacylglycerols from transgenic Camelina sativa. Ind Crop Prod 65:259-268. https://doi.org/10.1016/j.indcrop.2014.11.019

Lobo P, Christie S, Khandelwal B, Blakey SG, Raper DW (2015) Evaluation of non-volatile particulate matter emission characteristics of an aircraft auxiliary power unit with varying alternative jet fuel blend ratios. Energy Fuel 29(11):7705-7711. https://doi.org/10. 1021/acs.energyfuels.5b01758

Lohaus RH (2019) Camelina sativa: a promising oilseed for producing biofuels on marginal lands: field production and characterization of a low-pectin seed mutant. Doctoral dissertation, University of Nevada

Lolli S, Grilli G, Ferrari L, Battelli G, Pozzo S, Galasso I, Russo R, Brasca M, Reggiani R, Ferrante V (2020) Effect of different percentage of Camelina sativa cake in laying hens diet: performance, welfare, and eggshell quality. Animals 10:1396. https://doi.org/10.3390/ ani10081396

Luo Z, Brock J, Dyer JM, Kutchan T, Schachtman D, Augustin M, Ge Y, Fahlgren N, Abdel-Haleem H (2019) Genetic diversity and population structure of a Camelina sativa spring panel. Front Plant Sci 10: 184. https://doi.org/10.3389/fpls.2019.00184

Manca A, Pecchia P, Mapelli S, Masella P, Galasso I (2013) Evaluation of genetic diversity in a Camelina sativa $(\mathrm{L}$.) Crantz collection using microsatellite markers and biochemical traits. Genet Resour Crop Eviron 60(4):1223-1236. https://doi.org/10.1007/s10722-0129913-8

Manninen S, Lankinen M, de Mello V, Ågren J, Laaksonen D, Schwab U, Erkkilä A (2019) The effect of Camelina sativa oil and fish intakes on fatty acid compositions of blood lipid fractions. Nutr Metab Cardiovasc Dis 29(1):51-61. https://doi.org/10.1016/j. numecd.2018.10.002

Martinelli T, Galasso I (2011) Phenological growth stages of Camelina Sativa according to the extended BBCH scale. Ann Appl Biol 158(1):87-94. https://doi.org/10.1111/j.1744-7348.2010.00444.x

Martinez S, Alvarez S, Capuano A, del Mar Delgado M (2020) Environmental performance of animal feed production from Camelina sativa (L.) Crantz: influence of crop management practices under Mediterranean conditions. Agric Syst 177:102717. https://doi.org/10.1016/j.agsy.2019.102717

Masella P, Martinelli T, Galasso I (2014) Agronomic evaluation and phenotypic plasticity of Camelina Sativa growing in Lombardia, Italy. Crop Pasture Sci 65(5):453-460. https://doi.org/10.1071/ CP14025

Matthäus B, Angelini LG (2005) Anti-nutritive constituents in oilseed crops from Italy. Ind Crop Prod 21(1):89-99. https://doi.org/10. 1016/j.indcrop.2003.12.021

Matthäus B, Zubr J (2000) Variability of specific components in Camelina sativa oilseed cakes. Ind Crop Prod 12(1):9-18. https:// doi.org/10.1016/S0926-6690(99)00040-0

Mauri PV, Mostaza, D, Plaza A, Ruiz-Fernandez J, Prieto J, Capuano A (2019) Variability of camelina production in the center of Spain in two years of cultivation, a new profitable and alternative crop. In Proceeding of $27^{\text {th }}$ European Biomass Conference and Exhibition, 27-30 May 2019, 196-200. https://doi.org/10.5071/ 27thEUBCE2019-1BV.8.16

Meyer N, Bergez JE, Constantin J, Justes E (2019) Cover crops reduce water drainage in temperate climates: a meta-analysis. Agron Sustain Dev 39:3. https://doi.org/10.1007/s13593-018-0546-y

Morais S, Edvardsen RB, Tocher DR, Bell JG (2012) Transcriptomic analyses of intestinal gene expression of juvenile Atlantic cod (Gadus morhua) fed diets with Camelina oil as replacement for fish oil. Comp Biochem Physiol B: Biochem Mol Biol 161(3):283-293. https://doi.org/10.1016/j.cbpb.2011.12.004

Muśnicki C, Machnicka J, Adamczewski K (1967) Współrzędna uprawa lnianki jarej z innymi roślinami jarymi. Pam Puł 25:121-155

Na G, Aryal N, Fatihi A, Kang J, Lu C (2018) Seed-specific suppression of ADP-glucose pyrophosphorylase in Camelina sativa increases seed size and weight. Biotechnol Biofuels 11:330. https://doi.org/ 10.1186/s13068-018-1334-2

Nguyen HT, Park H, Koster KL, Cahoon RE, Nguyen HT, Shanklin J, Clemente TE, Cahoon EB (2015) Redirection of metabolic flux for high levels of omega-7 monounsaturated fatty acid accumulation in camelina seeds. Plant Biotechnol J 13(1):38-50. https://doi.org/10. 1111/pbi.12233

Orczewska-Dudek S, Pietras M (2019) The effect of dietary Camelina sativa oil or cake in the diets of broiler chickens on growth performance, fatty acid profile, and sensory quality of meat. Animal 9(10): 734. https://doi.org/10.3390/ani9100734

Ozseyhana ME, Kanga J, Mua X, Lua C (2018) Mutagenesis of the FAE1 genes significantly changes fatty acid composition in seeds of Camelina sativa. Plant Physiol Biochem 123:1-7. https://doi.org/ 10.1016/j.plaphy.2017.11.021

Paulsen HM (2007) Organic mixed cropping systems with oilseeds: 1. Yields of mixed cropping systems of legumes or spring wheat with false flax (Camelina sativa L. Crantz). Landbauforsch Völkenrode 57(1):107-117

Paulsen HM (2011) Improving green-house gas balances of organic farms by the use of straight vegetable oil from mixed cropping as farm own fuel and its competition to food production. Landbauforschung Völkenrode 61(3):209-216

Pecchia P, Russo R, Brambilla I, Reggiani R, Mapelli S (2014) Biochemical seed traits of Camelina Sativa - an emerging oilseed crop for biofuel: environmental and genetic influences. J Crop 
Improv 28(4):465-483. https://doi.org/10.1080/15427528.2014. 920758

Peiretti PG, Mussa PP, Prola L, Meineri G (2007) Use of different levels of false flax (Camelina sativa L.) seed in diets for fattening rabbits. Livest Sci 107(2-3):192-198. https://doi.org/10.1016/j.livsci.2006. 09.015

Pekel AY, Horn NL, Adeola O (2017) The efficacy of dietary xylanase and phytase in broiler chickens fed expeller-extracted camelina meal. Poult Sci 96:98-107. https://doi.org/10.3382/ps/pew183

Pekel AY, Patterson PH, Hulet RM, Acar N, Cravener TL, Dowler DB, Hunter JM (2009) Dietary camelina meal versus flaxseed with and without supplemental copper for broiler chickens: Live performance and processing yield. Poult Sci 88(11):2392-2398. https://doi.org/ 10.3382/ps.2009-00051

Petit S, Cordeau S, Chauvel B, Bohan D, Guillemin JP, Steinberg C (2018) Biodiversity-based options for arable weed management. A review. Agron Sustain Dev 38:48. https://doi.org/10.1007/s13593018-0525-3

Popa AL, Jurcoane S, Dumitriu B (2017) Camelina sativa oil-a review. Sci Bull Ser F Biotechnol 21:233-238

Quéro A, Molinié R, Mathiron D, Thiombiano B, Fontaine JX, Brancourt D, Van Wuytswinkel O, Petit E, Demailly H, Mongelard G, Pilard S, Thomasset B, Mesnard F (2016) Metabolite profiling of developing Camelina sativa seeds. Metabolomics 12:186. https://doi.org/ 10.1007/s11306-016-1135-1

Righini D, Zanetti F, Martínez-Force E, Mandrioli M, Gallina Toschi T, Monti A (2019) Shifting sowing of camelina from spring to autumn enhances the oil quality for bio-based applications in response to temperature and seed carbon stock. Ind Crop Prod 137:66-73. https://doi.org/10.1016/j.indcrop.2019.05.009

Righini D, Zanetti F, Monti A (2016) The bio-based economy can serve as the springboard for camelina and crambe to quit the limbo. OCL 23(5):D504. https://doi.org/10.1051/ocl/2016021

Rode J (2002) Study of autochthon Camelina sativa (L.) Crantz in Slovenia. J Herb Spic Med Plants 9:313-318

Rodríguez-Rodríguez MF, Sánchez-García A, Salas JJ, Garcés R, Martínez-Force E (2013) Characterization of the morphological changes and fatty acid profile of developing Camelina sativa seeds. Ind Crop Prod 50:673-679. https://doi.org/10.1016/j.indcrop.2013. 07.042

Rokka T, Alén K, Valajac J, Ryhänen EL (2002) The effect of a Camelina sativa enriched diet on the composition and sensory quality of hen eggs. Food Res Int 35(2-3, 253):-256. https://doi.org/10.1016/ S0963-9969(01)00193-4

Royo-Esnal A, Valencia-Gredilla F (2018) Camelina as a rotation crop for weed control in organic farming in a semiarid Mediterranean climate. Agriculture 8(10):156. https://doi.org/10.3390/ agriculture8100156

Ruiz-Lopez N, Haslam RP, Napier JA, Sayanova O (2014) Successful high-level accumulation of fish oil omega-3 long-chain polyunsaturated fatty acids in a transgenic oilseed crop. Plant J 77(2):198-208. https://doi.org/10.1111/tpj.12378

Russo R, Galasso I, Reggiani R (2014) Variability in glucosinolate content among camelina species. Am J Plant Sci 5(3):294-298. https:// doi.org/10.4236/ajps.2014.53040

Russo R, Reggiani R (2012) Antinutritive compounds in twelve Camelina sativa genotypes. Am J Plant Sci 3(10):1408-1412. https://doi.org/10.4236/ajps.2012.310170

Saucke H, Ackermann K (2006) Weed suppression in mixed cropped grain peas and false flax (Camelina sativa). Weed Res 46(6):453461. https://doi.org/10.1111/j.1365-3180.2006.00530.x

Schmidt S, Pokorný J (2005) Potential application of oilseeds as sources of antioxidants for food lipids-a review. Czech J Food Sci 23(3):93102. https://doi.org/10.17221/3377-CJFS
Schuster A, Friedt W (1998) Glucosinolate content and composition as parameters of quality of Camelina seed. Ind Crop Prod 7(2-3):297302. https://doi.org/10.1016/S0926-6690(97)00061-7

Scientific Advisory Committee on Nutrition (2004) Advice on fish consumption: benefits and risks. TSO, London

Shukla VKS, Dutta PC, Artz WE (2002) Camelina oil and its unusual cholesterol content. J Am Oil Chem Soc 79(10):965-969. https:// doi.org/10.1007/s11746-002-0588-1

Simopoulos AP (1991) Omega-3 fatty acids in health and disease and in growth and development. Am J Clin Nutr 54(3):438-463. https:// doi.org/10.1093/ajen/54.3.438

Simopoulos AP (2016) An increase in the omega-6/omega-3 fatty acid ratio increases the risk for obesity. Nutrients 8(3):128. https://doi. org/10.3390/nu8030128

Sindelar AJ, Schmer MR, Gesch RW, Forcella F, Eberle CA, Thom MD, Archer DW (2017) Winter oilseed production for biofuel in the US Corn Belt: opportunities and limitations. GCB Bioenergy 9(3):508524. https://doi.org/10.1111/gcbb.12297

Sitther V, Tabatabai B, Enitan O, Dhekney S (2018) Agrobacteriummediated transformation of Camelina sativa for production of transgenic plants. J Biol Methods 5(1):e83. https://doi.org/10.14440/jbm. 2018.208

Soorni J, Kazemitabar SK, Kahrizi D, Dehestani A, Bagheri N (2017) Screening of camelina (Camelina sativa L.) doubled haploid lines for freezing tolerance in the seedling stage. Genetika 49(1):173-181. https://doi.org/10.2298/GENSR1701173S

Stolarski MJ, Krzyżaniak M, Kwiatkowski J, Tworkowski J, Szczukowski S (2018) Energy and economic efficiency of camelina and crambe biomass production on a large-scale farm in northeastern Poland. Energy 150:770-780. https://doi.org/10.1016/j. energy.2018.03.021

Stolarski MJ, Krzyżniak M, Tworkowski J, Załuski D, Kwiatkowski J, Szczukowski S (2019) Camelina and crambe production - energy efficiency indices depending on nitrogen fertilizer application. Ind Crop Prod 137:386-395. https://doi.org/10.1016/j.indcrop.2019.05. 047

Struik PC, Kuyper TW (2017) Sustainable intensification in agriculture: the richer shade of green. A review. Agron Sustain Dev 37:39. https://doi.org/10.1007/s13593-017-0445-7

Szumacher-Strabel M, Cieslak A, Zmora P, Pers-Kamczyc E, Bielinska S, Staniszb M, Wojtowski J (2011) Camelina sativa cake improved unsaturated fatty acids in ewe's milk. J Sci Food Agric 91:20312037. https://doi.org/10.1002/jsfa.4415

Taranu I, Gras M, Pistol GC, Motiu M, Marin DE, Lefter N, Ropota M, Habeanu M (2014) $\omega$-3 PUFA rich camelina oil by-products improve the systemic metabolism and spleen cell functions in fattening pigs. PloS one 9(10): e110186. https://doi.org/10.1371/journal. pone. 0110186

Terpinc P, Polak T, Makuc D, Ulrih NP, Abramovič H (2012) The occurrence and characterisation of phenolic compounds in Camelina sativa seed, cake and oil. Food Chem 131(2):580-589. https://doi. org/10.1016/j.foodchem.2011.09.033

Tocher DR (2015) Omega-3 long-chain polyunsaturated fatty acids and aquaculture in perspective. Aquaculture 449:94-107. https://doi. org/10.1016/j.aquaculture.2015.01.010

Toncea I, Necseriu D, Prisecaru T, Balint LN, Ghilvacs MI, Popa M (2013) The seed's and oil composition of Camelia - first Romanian cultivar of camelina (Camelina sativa, L. Crantz). Rom Biotechnol Lett 18(5):8594-8602

Tonin P, Gosselet N, Halle E, Henrion M (2018) Ideal oil and protein crops - what are users ideotypes, from the farmer to the consumer? OCL 25(6):D605. https://doi.org/10.1051/oc1/2018060

Ubeyitogullari A, Ciftci ON (2020) Fabrication of bioaerogels from camelina seed mucilage for food applications. Food Hydrocoll 102:105597. https://doi.org/10.1016/j.foodhyd.2019.105597 
Vollmann J, Eynck C (2015) Camelina as a sustainable oilseed crop: contributions of plant breeding and genetic engineering. Biotechnol J 10(4):525-535. https://doi.org/10.1002/biot. 201400200

Vollmann J, Grausgruber H, Stift G, Dryzhyruk V, Lelley T (2005) Genetic diversity in camelina germplasm as revealed by seed quality characteristics and RAPD polymorphism. Plant Breed 124(5):446453. https://doi.org/10.1111/j.1439-0523.2005.01134.x

Vollmann J, Moritz T, Kargl C, Baumgartner S, Wagentristl H (2007) Agronomic evaluation of camelina genotypes selected for seed quality characteristics. Ind Crop Prod 26(3):270-277. https://doi.org/10. 1016/j.indcrop.2007.03.017

Von Cossel M, Lewandowski I, Elbersen B, Staritsky I, Van Eupen M, Iqbal Y, Mantel S, Scordia D, Testa G, Cosentino SL, Maliarenko O, Eleftheriadis I, Zanetti F, Monti A, Lazdina D, Neimane S, Lamy I, Ciadamidaro L, Sanz M, Carrasco JE, Ciria P, McCallum I, Trindade LM, Van Loo EN, Elbersen W, Fernando AL, Papazoglou EG, Alexopoulou E (2019) Marginal agricultural land low-input systems for biomass production. Energies 12(16):3123. https://doi.org/10.3390/en12163123

West AL, Miles EA, Lillycrop K, Han L, Sayanova O, Napier JA, Calder PC, Burdge GC (2019) Postprandial incorporation of EPA and DHA from transgenic Camelina sativa oil into blood lipids is equivalent to that from fish oil in healthy humans. Br J Nutr 121(11):1235-1246. https://doi.org/10.1017/s0007114519000825

Woyengo TA, Patterson R, Slominski BA, Beltranena E, Zijlstra RT (2016) Nutritive value of cold-pressed camelina cake with or without supplementation of multi-enzyme in broiler chickens. Poult Sci 95(10):2314-2321. https://doi.org/10.3382/ps/pew098

Yuan L, Li R (2020) Metabolic engineering a model oilseed Camelina sativa for the sustainable production of high-value designed oils. Front Plant Sci 11:11. https://doi.org/10.3389/fpls.2020.00011

Zając M, Kiczorowska B, Samolińska W, Klebaniuk R (2020) Inclusion of camelina, flax, and sunflower seeds in the diets for broiler chickens: apparent digestibility of nutrients, growth performance, health status, and carcass and meat quality traits. Animal 10(2): 321. https://doi.org/10.3390/ani10020321

Zaleckas E, Makarevičienė V, Sendžikienė E (2012) Possibilities of using Camelina sativa oil for producing biodiesel fuel. Transport 27(1): 60-66. https://doi.org/10.3846/16484142.2012.664827
Załuski D, Tworkowski J, Krzyżaniak M, Stolarski MJ, Kwiatkowski J (2020) The characterization of 10 spring camelina genotypes grown in environmental conditions in North-Eastern Poland. Agronomy 10(1):64. https://doi.org/10.3390/agronomy 10010064

Zanetti F, Christou M, Alexopoulou E, Berti MT, Vecchi A, Borghesi A, Monti A (2019) Innovative double cropping systems including camelina [Camelina sativa (L.) Crantz] a valuable oilseed crop for bio-based applications. In proceedings of $27^{\text {th }}$ European Biomass Conference and Exhibition. May 2019:127-130. https://doi.org/10. 5071/27theubce2019-1co.5.3

Zanetti F, Eynck C, Christou M, Krzyżaniak M, Righini D, Alexopoulou E, Stolarski MJ, Van Loo EN, Puttick D, Monti A (2017) Agronomic performance and seed quality attributes of camelina (Camelina sativa L. Crantz) in multi-environment trials across Europe and Canada. Ind Crop Prod 107:602-608. https://doi.org/ 10.1016/j.indcrop.2017.06.022

Zanetti F, Gesch RW, Walia MK, Johnson JMF, Monti A (2020) Winter camelina root characteristics and yield performance under contrasting environmental conditions. Field Crop Res 252:107794. https:// doi.org/10.1016/j.fcr.2020.107794

Zubr J (1997) Oil-seed crop: Camelina sativa. Ind Crop Prod 6(2):113119. https://doi.org/10.1016/S0926-6690(96)00203-8

Zubr J (2003) Dietary fatty acids and amino acids of Camelina sativa seed. J Food Qual 26(6):451-462. https://doi.org/10.1111/j.17454557.2003.tb00260.x

Zubr J (2009) Unique dietary oil from Camelina sativa seed. Agro Food Ind Hi Tec 20(2):42-46

Zubr J (2010) Carbohydrates, vitamins and minerals of Camelina sativa seed. Nutr Food Sci 40(5):523-531. https://doi.org/10.1108/ 00346651011077036

Zubr J, Matthäus B (2002) Effects of growth conditions on fatty acids and tocopherols in Camelina sativa oil. Ind Crop Prod 15(2):155-162. https://doi.org/10.1016/S0926-6690(01)00106-6

Publisher's note Springer Nature remains neutral with regard to jurisdictional claims in published maps and institutional affiliations. 